\title{
Bromeliaceae na regiẽo de Macaé de Cima, Nova Friburgo, Rio de JANEIRo, BRASIL ${ }^{1}$
}

\author{
Andrea Ferreira da Costa ${ }^{2,4}$ \& Tânia Wendt ${ }^{3}$
}

\section{RESUMO}

(Bromeliaceae na região de Macaé de Cima, Nova Friburgo, Rio de Janeiro, Brasil) São apresentadas as espécies de Bromeliaceae da região de Macaé de Cima, localizada em Nova Friburgo, Rio de Janeiro, abrangendo uma área de ca. 7.000 hectares de Floresta Pluvial Atlântica montana e alto-montana. São encontradas 51 espécies subordinadas a 14 gêneros, dentre as quais se destacam: Vriesea (19 spp.), Neoregelia (5 spp.), Aechmea, Nidularium e Tillandsia (com 4 spp. cada). São apresentadas chave de identificação das espécies, descrições, e informações sobre floração, frutificação, distribuição geográfica e hábitats.

Palavras-chave: Mata Atlântica, levantamento florístico, taxonomia, identificação, distribuição geográfica.

\section{Abstract}

(Bromeliaceae of the Macaé de Cima Region, Nova Friburgo, Rio de Janeiro, Brazil) The Macaé de Cima region is located in Nova Friburgo, Rio de Janeiro, and includes about 7.000 hectares of montane atlantic forest. Fifty-one species under 14 genera were found, where the richest are: Vriesea (19 spp.), Neoregelia (5 spp.), Aechmea, Nidularium and Tillandsia (with 4 spp. each one). Key for the species, descriptions, and comments on the phenology, habitats, and distribution are included

Key-words: Atlantic Forest, floristics, taxonomy, botanical survey, identification, distribution.

\section{INTRODUÇÃo}

A família Bromeliaceae, com cerca de 3.010 espécies (Luther 2004) e 56 gêneros (Grant \& Zijlstra 1998), é típica das zonas tropicais e subtropicais das Américas, sendo que apenas uma espécie (Pitcairnia feliciana (A. Chev.) Harms \& Mildbr.) ocorre na África, na região da Guiné (Smith \& Downs 1974; Porembski \& Barthlott 1999). São encontradas nas mais variadas condições de altitude, temperatura e umidade e apresentam sofisticadas adaptações ao hábito epifítico, podendo ser epífitas obrigatórias ou facultativas (Benzing 2000). Muitas de suas espécies são também terrícolas, saxícolas ou rupícolas, e recentemente foi registrado o fato de também vegetarem em solos sujeitos a inundações periódicas (Scarano et al. 1997). Após os mais importantes tratamentos para a família (Mez 1892-4, 1896, 1934-5; Smith 1955; Smith \& Downs 1974, 1977, 1979), o estudo taxonômico das Bromeliaceae incluiu a publicação de novas espécies, a segregação de gêneros nas três subfamílias (Luther 2001;
Luther \& Sieff 1994, 1997 a, b), além de diversas floras regionais (e.g. Wanderley \& Mollo 1992; Wendt 1994; Sousa \& Wanderley 2000; Wanderley \& Forzza 2003; Barros 2006; Vieira 2006; Siqueira-Filho \& Leme 2006; Moura et al. 2007) revisões de gêneros, subgêneros e complexos de espécies (e.g. Leme 1997, 1998, 2000; Wendt 1997; Costa 2002; Sousa 2004a; Sousa 2004b; Forzza 2005; Faria 2006).

Para o estado do Rio de Janeiro, foram registrados 314 táxons entre espécies e variedades (Fontoura et al. 1991). Deste total, mais de $80 \%$ ocorre na Floresta Pluvial Atlântica, dos quais $26 \%$ são exclusivos desta formação. Considerando-se a importância da família na flora fluminense, são ainda escassos os trabalhos florístico-taxonômicos do estado (e.g. Costa 1993; Vidal 1995; Vieira 2006; Barros 2006), sendo mais comuns as listagens florísticas em remanescentes florestais (Costa et al. 1997; Costa et al. 2001; Lima \& Guedes-Bruni 1997a; Nunes-Freitas 2005), ou nas restingas (Cogliatti-Carvalho et al. 2001; Moura et al. 2007).

Artigo recebido em 01/2007. Aceito para publicação em 09/2007.

${ }^{1} \mathrm{O}$ tratamento das espécies do gênero Vriesea constituiu parte da Dissertação de Mestrado da primeira autora, desenvolvida no Programa de Pós-Graduação em Ciências Biológicas (Botânica) do Museu Nacional/UFRJ.

${ }^{2}$ Departamento de Botânica-Museu Nacional-UFRJ, Quinta da Boa Vista, São Cristóvão, 20940-040, Rio de Janeiro/RJ. ${ }^{3}$ Departamento de Botânica-Instituto de Biologia-UFRJ, Cidade Universitária, Ilha do Fundão, 21941-590, Rio de Janeiro/RJ.

${ }^{4}$ afcosta@acd.ufrj.br (autor para correspondência) 
A região de Macaé de Cima, situada no município de Nova Friburgo, Rio de Janeiro, apresenta importantes áreas remanescentes de Mata Atlântica. Sua flora é especialmente rica sendo conhecidas 1023 táxons específicos e infra-específicos subordinados a 104 famílias de espermatófitas (Lima \& Guedes-Bruni 1997b). As Bromeliaceae foram apontadas como a sexta família com maior número de espécies (36 spp.) entre as angiospermas (Lima \& GuedesBruni 1997b) e a segunda entre aquelas com representantes epífitos (Fontoura et al. 1997).

Os objetivos do presente trabalho foram atualizar da lista florística fornecida por Guedes-Bruni \& Lima (1994), contribuir para o conhecimento da flora da Mata Atlântica e fornecer subsídios para futuros estudos taxonômicos na família.

\section{Material e Métodos}

O trabalho aqui apresentado foi realizado na antiga Reserva Ecológica de Macaé de Cima (REMC), uma unidade de conservação criada em janeiro de 1990, pela Prefeitura Municipal de Nova Friburgo, mas que nunca chegou a ter sua situação regulamentada. Atualmente parte de sua área encontra-se incluída na APA de Macaé de Cima e parte no Parque Estadual dos Três Picos.

As informações relativas à vegetação $\mathrm{e}$ à flora da REMC encontram-se em Lima \& Guedes-Bruni $(1994,1996)$ e Lima \& GuedesBruni (1997a). O tratamento das espécies foi realizado com base em coletas de material entre os anos de 1988 e 1993, durante o desenvolvimento dos estudos do Programa Mata Atlântica/Jardim Botânico do Rio de Janeiro na área, e complementados com levantamento na literatura. O material coletado encontra-se, em sua maioria, depositado no
Herbário do Instituto de Pesquisas Jardim Botânico do Rio de Janeiro (RB). As descrições foram feitas com base no material coletado na região. A terminologia utilizada nas descrições morfológicas foi aquela habitualmente adotada para a família (Smith \& Downs 1974, 1977, 1979) com algumas modificações. Para a maioria das estruturas foram consultados Radford (1986), e para as inflorescências Weberling (1989). Após a citação da obra original de cada espécie é informada, quando oportuno, uma ou mais referências de interesse para o táxon. Para aquelas espécies que sofreram combinações ou foram reduzidas desde a lista de Guedes-Bruni \& Lima (1994), são fornecidos o nomes desta lista na sinonímia. Não foram adotadas categorias infra-específicas. As informações sobre a distribuição geográfica foram retiradas de Smith \& Downs (1974, 1977, 1979), de revisões recentes dos grupos, e complementadas com informações de herbários. Os padrões de distribuição geográfica foram discutidos com base em Lima et al. (1997).

\section{Resultados e Discussão}

Na região de Macaé de Cima ocorrem 14 gêneros e 51 espécies de Bromeliaceae, sendo cinco descritas pela primeira vez durante o desenvolvimento do projeto, demonstrando a importância de floras locais e regionais para a taxonomia e conservação.

As espécies Neoregelia farinosa (Ule) L.B.Sm. e N. macahensis (Ule) L.B.Sm., descritas para a região de Macaé de Cima com base em material coletado por Ule (4961 e 4960, respectivamente) (Smith \& Downs 1979) não foram recoletadas e seus materiaistipo depositados no Herbário de Berlin (B) não foram analisados, e por isso não foram tratadas no presente estudo.

\section{Chave para identificação das espécies}

1. Folhas de margem inteira. Ovário súpero. Fruto cápsula; sementes com apêndices.

2. Plantas terrestres, saxícolas ou rupícolas, nunca epífitas. Folhas formando rosetas irregulares sem tanque. Apêndices da semente inteiros, caudados nos pólos. ........... Pitcairnioideae

3. Sépalas fortemente alado-carenadas. 1. Pitcairnia carinata

3'. Sépalas não alado-carenadas. 2. Pitcairnia flammea 
2'. Plantas geralmente epífitas. Folhas formando rosetas regulares, com ou sem tanque. Nos casos onde o tanque for ausente, são sempre epífitas. Apêndices da semente plumosos, coma apical. Tillandsioideae

4. Roseta formando tanque.

5. Inflorescência simples.

6. Inflorescência geralmente secundiflora na antese.

7. Bainha com estrias irregulares transversais atropurpúreas; lâmina ca. $5 \mathrm{~mm}$ larg. Escapo curvo; brácteas do escapo com base elíptica e ápice linear longo atenuado. Pétalas lineares, verdes, apêndices liguliformes obtusos; estames exsertos. 12. Vriesea arachnoidea

7'. Bainha totalmente verde ou castanha; lâmina 2,5-3,5 cm larg. Escapo ereto; brácteas do escapo ovadas e agudas. Pétalas obovadas, amarelas, apêndices liguliformes agudos; estames inclusos.

8. Brácteas florais $2-3 \mathrm{~cm}$ compr., verdes e lisas quando jovens, passando a estramíneas na frutificação. 23. Vriesea longiscapa

8'. Brácteas florais $3-4 \mathrm{~cm}$ compr., castanho-avermelhadas, lisas e quebradiças, com ápice e margem estramíneos. 22. Vriesea longicaulis

6'. Inflorescência não secundiflora.

9. Roseta utriculosa. Flores polísticas.

16. Vriesea flammea

9'. Roseta infundibuliforme. Flores dísticas.

10. Planta robusta, $100-180 \mathrm{~cm}$ alt. quando florida. Brácteas florais com aurícula decurrente na base. Flores patentes a reflexas; pétalas obovadas; estames inclusos.

11. Folhas obtusas e acuminadas, geralmente com mácula atropurpúrea no ápice. Inflorescência recoberta por substância gelatinosa fortemente odorífera. Brácteas florais verdes. 14. Vriesea bituminosa

11'. Folhas acuminadas, sem mácula no ápice. Inflorescência recoberta por substância gelatinosa inodora; brácteas florais castanhas, margem verde com máculas atropurpúreas. 13. Vriesea atra

10'. Planta florida $23-50 \mathrm{~cm}$ alt. Brácteas florais sem aurículas decurrentes na base. Flores eretas a patentes; pétalas lineares; estames exsertos.

12. Brácteas florais infladas.

13. Lâmina oblanceolada. Inflorescência oblonga; brácteas florais com ápice fortemente incurvado, margem formando forte curva, imbricadas por $1 / 3$ da sua largura.

18. Vriesea heterostachys

13'. Lâmina linear. Inflorescência elíptica ou ovada; brácteas florais levemente incurvadas, margem formando curva suave, imbricadas por $1 / 2$ da sua largura. 21. Vriesea inflata

12'. Brácteas florais não infladas.

14. Inflorescência ca. $3,5 \mathrm{~cm}$ compr., quadrada a oblonga; brácteas florais 2,5-3×1-1,2 cm; flores geralmente patentes na antese. 15. Vriesea carinata

14'. Inflorescência 9-11 cm compr., oblonga; brácteas florais 3,5$4,5 \times 2,2-2,6 \mathrm{~cm}$; flores sub-eretas na antese.

24. Vriesea paraibica

5'. Inflorescência composta.

15. Inflorescência em racemo heterotético ou espiga, duplo ou triplo. 
16. Roseta utriculosa. Folhas com bainha atropupúrea na face ventral, lâmina subulada, atenuada. 5. Racinaea aeris-incola

16'. Roseta infundibuliforme. Folhas com bainha castanha a alvacenta; lâmina linear.

17. Planta estolonífera. 29. Vriesea vagans

17'. Planta não estolonífera.

18. Inflorescência não secundiflora; brácteas florais largo-ovadas, obtusas. Estames inclusos. 6. Racinaea spiculosa

18'. Inflorescência secundiflora pelo menos na antese; brácteas florais ovadas ou elípticas, agudas. Estames exsertos.

19. Lâmina obtusa e apiculada, $4,5-5 \mathrm{~cm}$ larg., verde com ápice purpúreo. Brácteas florais 2,5-2,8 cm compr.; sépalas 2,8 cm compr.; pétalas amarelas. 25. Vriesea philippocoburgii 19'. Lâmina acuminada, 1,7-2 cm larg., totalmente verde. Pétalas alvas. 20. Brácteas florais até $1 \mathrm{~cm}$ compr.; sépalas 1,3-1,5 cm compr....... 27. Vriesea sparsiflora 20 '. Brácteas florais 1,5-2 cm compr.; sépalas $2 \mathrm{~cm}$ compr.

26. Vriesea procera

15'. Inflorescência sempre em racemo heterotético duplo.

21. Pétalas $7-10 \mathrm{~cm}$ compr., espiralado-recurvadas na antese. Semente com apêndice apical ca. $1 \mathrm{~cm}$ compr.

22. Rupícola. Lâmina ca. $10 \mathrm{~cm}$ larg. Ramos da inflorescência ca. 27 cm compr. com 17-22 flores secundas para cima. Pétalas alvas. 3. Alcantarea imperialis 22'. Terrestre. Lâmina 4-6 cm larg. Ramos da inflorescência ca. 14 cm compr. com 57 flores dísticas não secundas. Pétalas amarelas. 4. Alcantarea nevaresii 21'. Pétalas 2,8-4 cm compr., eretas na antese. Semente com apêndice apical até $3 \mathrm{~mm}$ compr. 23. Lâmina com bandas transversais largas, irregulares e atropurpúreas.

19. Vriesea hieroglyphica

23'. Lâmina com estrias transversais de um verde pouco mais escuro.

24. Brácteas do escapo, primárias e florais lustrosas verdes. Brácteas florais 3-3,5 cm compr.; sépalas 3-4 cm compr. 20. Vriesea hydrophora 24'. Brácteas do escapo, primárias e florais amarelas, amarelo-esverdeadas ou vermelhas. Brácteas florais 1,6-3 cm compr.; sépalas 2-2,5 cm compr.

25. Bainhas com faixa castanha na base; lâmina aguda. Inflorescência cilíndrica, densa, raque amarela ou verde; brácteas florais 1,6-2,5 cm compr.

11. Vriesea altomacaensis

25'. Bainha atropurpúrea; lâmina obtusa. Inflorescência ampla, laxa; raque vermelha; brácteas florais $2,5-3 \mathrm{~cm}$ compr.

26. Inflorescência secundiflora na antese; brácteas florais $2-2,5 \mathrm{~cm}$ larg.; estames exsertos. 17. Vriesea garlippiana 26 '. Inflorescência não secundiflora na antese; brácteas florais ca. 1,5 cm larg.; estames inclusos. 28. Vriesea triligulata

4'. Roseta não formando tanque.

27. Folhas maleáveis.

28. Inflorescência em racemo heterotético duplo; brácteas florais $0,7-1,2 \mathrm{~cm}$ compr., triangulares, carenadas. 7. Tillandsia geminiflora

28'. Inflorescência em racemo ou raramente em racemo heterotético duplo; brácteas florais 1,8-2,5 cm compr., largo-elípticas, não carenadas. 8. Tillandsia roseiflora 
27'. Folhas rígidas. Inflorescência em racemo ou espiga.

29. Inflorescência em racemo. Brácteas florais largo-ovadas, obtusas e apiculadas, rosa. Pétalas liláses. 9. Tillandsia stricta 29'. Inflorescência em espiga. Brácteas florais elípticas, agudas, vinosas. Pétalas alvas. 10. Tillandsia tenuifolia

1'. Folhas de margem serrada ou serrilhada. Ovário ínfero, fruto baga semente sem apêndices..... Bromelioideae

30. Roseta não formando tanque, plantas terrestres. Inflorescência estrobiliforme, encimada por coroa de brácteas estéreis, semelhante a um pequeno abacaxi. ... 34. Ananas bracteatus

30 '. Roseta formando tanque, plantas geralmente epífitas.

31. Inflorescência umbeliforme ou capituliforme, geralmente embutida na roseta.

32. Flores pediceladas.

33. Escapo evidente, ca. $20 \mathrm{~cm}$ compr., inflorescência sobressaindo da roseta; brácteas florais cobertas por lanugem castanha. 39. Edmundoa lindenii

33'. Escapo não evidente, 5-8 cm compr., inflorescência embutida na roseta; brácteas florais não cobertas por lanugem castanha.

34. Inflorescência em racemo heterotético duplo; brácteas florais ca. $5 \mathrm{~cm}$ compr., estreito-triangulares, longo-atenuadas, serrilhadas, levemente carenadas. 42. Neoregelia lymaniana

34'. Inflorescência em racemo; brácteas florais lineares ou lanceoladas, inteiras, não carenadas.

35. Brácteas florais $4-5 \mathrm{~cm}$ compr., retusas ou obtusas.

36. Folhas internas com terço mediano rosa na floração. Pétalas liláses. 40. Neoregelia carolinae

36 '. Folhas verdes com máculas esparsas vinosas. Pétalas vinosas com ápice alvo.

42. Neoregelia leucophoea 35'. Brácteas florais 2-3 cm compr., agudas.

37. Folhas verdes. Sépalas ca. 1,5 cm compr.; pétalas não observadas.

41. Neoregelia fluminensis

$37^{\prime}$. Folhas verdes com mancha roxa no ápice. Sépalas ca. $4,5 \mathrm{~cm}$ compr.; pétalas ca. $10 \mathrm{~cm}$ compr., alvas com ápice e margem purpúreos. 44. Neoregelia tenebrosa

32'. Flores sésseis.

38. Brácteas do escapo 9-40 cm compr., foliáceas. Pétalas alvas com ápice azul.

39. Escapo $30 \mathrm{~cm}$ compr.; brácteas do escapo $22-40 \mathrm{~cm}$ compr.; brácteas primárias 9-13 cm compr.

47. Nidularium procerum

39'. Escapo 7-10 cm compr.; brácteas do escapo 9-22 cm compr.; brácteas primárias $4,5-11 \mathrm{~cm}$ compr. 48. Nidularium scheremetiewii

38'. Brácteas do escapo 3,5-7 cm compr., não foliáceas. Pétalas alvas ou verdes com ápice alvo.

40. Pétalas com lacínias patentes e acuminadas. Brácteas florais ca. 1,3 $\mathrm{cm}$ compr., não carenadas. Sépalas ca. $1,3 \mathrm{~cm}$ compr., concrescidas por ca. $0,3 \mathrm{~cm}$, não carenadas. 38. Canistropsis microps

40'. Pétalas com lacínias eretas, obtusas e cuculadas.

41. Inflorescência sobressaindo da roseta; brácteas florais triangulares, agudas, ca. $3 \mathrm{~cm}$ compr., irregularmente serrilhadas, levemente carenadas no ápice. Sépalas não carenadas. 46. Nidularium longiflorum 
41'. Inflorescência embutida na roseta; brácteas florais elípticas, obtusas, ca. 2,5 cm compr., inteiras, carenadas na base. Sépalas levemente carenadas em direção ao ápice.

45. Nidularium innocentii

31'. Inflorescência rômbica, cilíndrica, piramidal ou estrobiliforme, laxa ou densa, sobressaindo da roseta, com escapo desenvolvido.

42. Flores de 6-7 cm compr.; pétalas recurvadas, com mais de $4 \mathrm{~cm}$ compr.; ovário sulcado.

43. Brácteas florais $1,2-2,3 \mathrm{~cm}$ compr.

37. Billbergia sanderiana

43'. Brácteas florais escamiformes ou ausentes.

44. Brácteas do escapo vermelhas; sépalas verdes com ápice azul; pétalas verdeamareladas.

35. Billbergia amoena

44'. Brácteas do escapo e sépalas rosa; pétalas rosa ou amarelas de ápice lilás a roxo.

36. Billbergia pyramidalis

42'. Flores 1-5,5 cm compr.; pétalas eretas, até $3,5 \mathrm{~cm}$ compr.; ovário não sulcado.

45. Sépalas de $1-2 \mathrm{~cm}$ compr.; pétalas de $2,8-3,5 \mathrm{~cm}$ compr.

46. Inflorescência laxa, raque visível; brácteas florais $0,8-1,8 \times 0,4-0,5 \mathrm{~cm}$; não recobrindo as flores.

50. Quesnelia liboniana

46'. Inflorescência densa, raque não visível; brácteas florais $3-4 \times 1,3-1,8 \mathrm{~cm}$, recobrindo as flores.

47. Inflorescência rômbica, 4-4,5 cm larg.; brácteas florais ca. $4 \times 1,3 \mathrm{~cm}$.....

51. Quesnelia strobilispica

47’. Inflorescência cilíndrica, 1,5-2 cm larg.; brácteas florais ca. $3 \times 1,8 \mathrm{~cm} . \ldots$

49. Quesnelia lateralis

45'. Sépalas de 0,3-1,5 cm compr.; pétalas de 1-2,5 cm compr.

48. Inflorescência em espiga dupla, piramidal.

49. Brácteas do escapo, primárias e florais serrilhadas..... 30. Aechmea caesia

49'. Brácteas do escapo, primárias e florais inteiras. .... 31. Aechmea coelestis

48'. Inflorescência espiga, estrobiliforme.

50. Inflorescência de 10-15 $\times 6 \mathrm{~cm}$; bráctea floral terminando em espinho de 1-2 cm compr.; pétalas liláses. 32. Aechmea ornata

50'. Inflorescência de 4-7×2-3 cm larg.; bráctea floral terminando em espinho de ca. 0,5 cm compr.; pétalas amarelas. 33. Aechmea pineliana

\section{Subfamília Pitcairnioideae}

1. Pitcairnia carinata Mez in Mart., Eichler \& Urban, Fl. bras. 3(3): 448. 1894; Smith \& Downs, Fl. Neotrop. Monogr. 14(1): 347-8. 1974; Wendt, Selbyana 15(2): 70-75, fig. 5. 1994.

Planta florida $25-35 \mathrm{~cm}$ alt., terrestre, rupícola ou saxícola. Folhas $20-30 \mathrm{~cm}$ compr.; bainha ovada, $2-5 \times 2-2,5 \mathrm{~cm}$, vinosa; lâmina subulada, atenuada, $1,8-2 \mathrm{~cm}$ larg., verdes até vinosas. Escapo ereto, $12-22 \mathrm{~cm}$ compr., avermelhado; brácteas do escapo foliáceas, longo-atenuadas, 6-18 cm compr., mais longas que os entrenós, verde-avermelhadas. Inflorescência em racemo, $4-7 \times 2 \mathrm{~cm}$, densa; brácteas florais ovadas, acuminadas, 1,5-2,5 $\times$ $0,7-1,8 \mathrm{~cm}$, igualando ou excedendo os pedicelos, não carenada, avermelhadas. Flores polísticas, suberetas, pedicelos delgados, ca. 1,5 cm compr.; sépalas triangulares, agudas, $2-2,5 \mathrm{~cm}$ compr., fortemente alado-carenadas, vermelhoalaranjado; corola zigomorfa na antese, com pétalas espatuladas, agudas, 5-5,5 cm compr., eretas, vermelhas, sem apêndices; estames exsertos. Distribuição geográfica e habitat: Rio de Janeiro (Smith \& Downs 1974), Espírito Santo e Minas Gerais (Wendt 1994). Endêmica da Floresta Pluvial Atlântica alto-montana, 1.2001.800 m.s.m, como terrestre, rupícola e saxícola. Material examinado: 4.XII.1991, fl., T. Wendt \& A. Costa 221 (RB).

Material adicional examinado: Nova Friburgo, $A$. F. Glaziou 13256 (B, holótipo; HB, foto do holótipo). 
2. Pitcairnia flammea Lindl., Bot. Reg. 13: 1092. 1827; Smith \& Downs, Fl. Neotrop. Monogr. 14(1): 348-51, fig.121 A-D. 1974; Wendt, Selbyana 15(2): 70-75, fig. 6. 1994.

Planta florida $50-80 \mathrm{~cm}$ alt., terrestre, rupícola ou saxícola. Folhas 40-90 cm compr.; bainha ovada, 1,5-4×2-3 cm, castanha; lâmina subulada, atenuada, 1-2,5 cm larg., verde. Escapo ereto, 27-45 cm compr., verde; brácteas do escapo foliáceas, atenuadas, $1,5-4,5 \mathrm{~cm}$ compr., mais longas que os entrenós, verdes. Inflorescência em racemo, 10-30 × 3-6 cm, densa; brácteas florais estreito-triangulares, atenuadas, $1-2,5 \times 0,3 \mathrm{~cm}$, não carenadas, verdes. Flores polísticas, suberetas, pedicelos delgados, 1-2 cm compr.; sépalas triangulares, agudas, 1,5-3,5 cm compr., não carenadas, vermelhas; corola zigomorfa na antese, com pétalas espatuladas, acuminadas, 5-6 cm compr., eretas, vermelhas, sem apêndices; estames exsertos. Distribuição geográfica e habitat: Ceará, Paraíba, Bahia, Minas Gerais, Espírito Santo, Rio de Janeiro, São Paulo, Paraná e Santa Catarina (Smith \& Downs 1974, Wendt 1994). Floresta Pluvial Atlântica montana e altomontana, nos afloramentos rochosos próximos do mar e nas restingas; como terrestre, rupícola e saxícola sobre paredões úmidos ou às margens de cursos d'água.

Material examinado: 15.IV.1991, fl., A. Costa et al. 360 (RB); 2.XII.1991, fl., A. Costa et al. 412 (RB); 27.XI.1986, fl., G. Martinelli et al. 11949 (RB); 26.VIII.1987, fl., M. Leitman et al. 289 (RB); 24.IX.1988, fl., M. Nadruz et al. 439 (RB); 3.XII.1991, fl., T. Wendt \& A. Costa 215 (RB); 4.XII.1991, fl., T. Wendt \& A. Costa 220 (RB).

\section{Subfamília Tillandsioideae}

3. Alcantarea imperialis (Carrière) Harms in Engler \& Prantl, Nat. Pflanzenfam. ed. 2, 15a: 126. 1930; Grant, Trop. Subtrop. Pflanzenw. 91: 7-15. 1995.

EVriesea imperialis Carrière, Rev. Hort. 60: 58. 1888; Smith \& Downs, Fl. Neotrop. Monogr. 14(2): 1268, fig. 425 A-F. 1977.

Planta robusta, florida até $3 \mathrm{~m}$ alt., rupícola. Folhas eretas, ca. $1 \mathrm{~m}$ compr., formando roseta infundibuliforme ampla; bainha largo-oblonga, ca. $25 \times 18-20 \mathrm{~cm}$, castanha; lâmina triangular, aguda, ca. $10 \mathrm{~cm}$ larg., verde ou vinosa. Escapo ereto, robusto, verde ou vinoso; brácteas do escapo inferiores foliáceas, as superiores com bainha ovada e lâmina triangular, longo-atenuada, ca. $25 \mathrm{~cm}$ compr., mais longas que os entrenós, porém recurvadas e expondo o escapo, vinosas ou verdes. Inflorescência em racemo heterotético duplo, ca. 1,5 m compr., secundiflora, densa; brácteas primárias inferiores semelhantes às do escapo, ca. $15 \mathrm{~cm}$ compr., as superiores ovadas, acuminadas, ca. $10 \mathrm{~cm}$ compr.; ramos ca. $27 \mathrm{~cm}$ compr., patentes, sem brácteas estéreis no pedúnculo, raque geniculada, vinosa a verde, 17-22 flores; brácteas florais elípticas, agudas, 2,5-3×1,5$2 \mathrm{~cm}$, mais curtas que as sépalas, carenadas em direção ao ápice, verdes com nuances vinosas. Flores dísticas, suberetas, secundas para cima, pedicelos robustos, ca. $1 \mathrm{~cm}$ compr.; sépalas obovadas, obtusas, ca. $3 \mathrm{~cm}$ compr., sem carenas, verdes; pétalas lineares, ca. $10 \mathrm{~cm}$ compr., livres, espiralado-recurvadas na antese, alvas, apêndices lineares; estames exsertos. Sementes com apêndice apical ca. $1 \mathrm{~cm}$ compr.

Distribuição geográfica e habitat: Rio de Janeiro (Smith \& Downs 1977, Fontoura et al. 1991) e Minas Gerais. Ocorre nas escarpas íngremes dos campos de altitude, formando densas populações.

Material examinado: 10.XII.1992, fl., G. Martinelli 14727 (RB); 22.XII.1992, f1., G. Martinelli 14799 (RB).

Devido ao seu porte majestoso e a facilidade de cultivo, A. imperialis tem sido elemento freqüente em projetos paisagísticos em todo o país. Para suprir a demanda do comércio de plantas ornamentais, as populações desta espécie têm sofrido forte impacto devido ao extrativismo, o que coloca em risco sua sobrevivência (Martinelli 1997). A população da área de estudo apresenta indivíduos com rosetas e brácteas do escapo totalmente verdes ou totalmente vinosas (Barbará et al. 2007).

4. Alcantarea nevaresii Leme, Bromélia 2(3): 15-23. 1995.

Planta robusta, florida ca. 1,5 m alt., terrestre. Folhas eretas, 65-85 cm compr., 
formando roseta infundibuliforme ampla; bainha quadrada, 8-12 $\times 8-12 \mathrm{~cm}$, castanhoescura em ambas as faces ou castanho-clara na face ventral; lâmina triangular, acuminada e recurvada no ápice, 4-6 cm larg., verde. Escapo ereto, 45-75 cm compr., vermelho; brácteas do escapo inferiores foliáceas, as superiores com bainha ovada e lâmina triangular, longo-atenuada, 14-18 cm compr., mais longas que os entrenós, porém recurvadas e expondo o escapo, vermelhas na metade inferior e verdes na superior. Inflorescência em racemo heterotético duplo, 45-70 × 18$20 \mathrm{~cm}$, não secundiflora; brácteas primárias inferiores semelhantes às do escapo, 9-12 cm compr., as superiores ovadas, acuminadas, ca. $5 \mathrm{~cm}$ compr.; ramos ca. 18, densos, ca. $14 \mathrm{~cm}$ compr., patentes, apresentando até 2 brácteas carenadas e estéreis na parte superior do pedúnculo, raque geniculada, vermelha, 5-7 flores; brácteas florais ovadas, agudas, incurvadas, 2-2,5×1,6-2 cm, mais curtas que as sépalas, carenadas em direção ao ápice, amarelas. Flores dísticas, suberetas, pedicelo robusto, ca. 0,7 cm compr.; sépalas obovadas, obtusas, ca. 2,5 cm compr., sem carena, amareloesverdeadas; pétalas lineares, ca. 7 cm compr., livres, espiralado-recurvadas na antese, amarelas, apêndices lineares e obtusos, ca. 18 mm compr.; estames exsertos. Sementes com apêndice apical ca. $1 \mathrm{~cm}$ compr.

Distribuição geográfica e habitat: Rio de Janeiro. Forma populações terrestres nos campos de altitude, entre os municípios de Teresópolis e Nova Friburgo.

Material examinado: 16.IV.1991, fr., A. Costa et al. 372 (RB); 16.XII.1992, bot., A. Costa et al. 437 (RB).

A espécie apresenta afinidades morfológicas com A. geniculata (Wawra) J. R. Grant e $A$. duarteana (L.B.Sm.) J. R. Grant (Leme 1995).

5. Racinaea aerisincola (Mez) M. A. Spencer \& L.B.Sm., Phytologia 74(2): 151-160. 1993.

三 Tillandsia aerisincola Mez, DC. Monogr. phan. 9: 759. 1896; Smith \& Downs, Fl. Neotrop. Monogr. 14(2): 1060, fig. 342 G-I. 1977.

Planta florida $20-40 \mathrm{~cm}$ alt., epífita. Folhas recurvadas, 15-24 cm compr., as mais externas de menores dimensões, reduzidas até ca. 1,5 cm compr., formando roseta utriculosa.; bainha largo-ovada, 2,5-6 × 2,5-4,5 cm, atropurpúrea na face ventral e castanha na face dorsal, com máculas atropurpúreas na parte superior; lâmina subulada, atenuada, às vezes com margem ondulada, $0,3-0,5 \mathrm{~cm}$ larg., verdes com máculas atropurpúreas. Escapo ereto a curvo, 10-16 cm compr., atropurpúreo; brácteas do escapo ovadas, longo-atenuadas, 1,5-7 cm compr., envolvendo o escapo, base atropurpúrea e ápice verde com máculas. Inflorescência em espiga dupla ou tripla, 14-26 cm compr., não secundiflora, laxa; brácteas primárias estreito-ovadas, agudas, 2,5-6 cm compr., atropurpúreas; ramos 6-10, 2,5-7 cm compr., raque geniculada; brácteas florais ovadas, agudas, $0,4-0,5 \times 0,3 \mathrm{~cm}$, não carenadas, atropurpúreas. Flores dísticas, sésseis; sépalas oblongas, ligeiramente assimétricas, obtusas, ca. 0,4 cm compr., não carenadas, verdes; pétalas ovadas, agudas, ca. $0,3 \mathrm{~cm}$ compr., mais curtas que as sépalas, alvas, sem apêndices; estames inclusos.

Distribuição geográfica e habitat: Espírito Santo, Rio de Janeiro, São Paulo, Paraná e Santa Catarina (Smith \& Downs 1977) e Minas Gerais. Floresta Pluvial Atlântica montana e alto-montana entre 50-1.300 m.s.m.

Material examinado: 2.II.1992, fl., fr. e bot., A. Costa et al. 417 (RB);22.I.1994, fr., C. M. Vieira \& L. C. Gurken 518 (RB); 6.III.1986, fr., H.C. Lima et al. 2676 (RB).

Ule (1900) descreve para a região de Macaé de Cima a espécie Catopsis deflexa considerada por Smith \& Downs (1977) como sinônimo de Tillandsia aerisincola. Racinaea aerisincola ocorre como epífita e é pouco freqüente na área.

6. Racinaea spiculosa (Griseb.) M.A.Spencer \& L.B.Sm., Phytologia 74(2): 151-160. 1993. 三 Tillandsia spiculosa Griseb., Nachr. Ges. Wiss. Goett. "1864": 17. 1865; Smith \& Downs, Fl. Neotrop. Monogr. 14(2): 1032-6, fig. 332. 1977.

Planta florida ca. $62 \mathrm{~cm}$ alt., epífita. Folhas suberetas, $27-30 \mathrm{~cm}$ compr., formando roseta infundibuliforme; bainha largo-ovada, ca. $12 \times 8 \mathrm{~cm}$, castanha; lâmina linear, acuminada, 
ca. $3 \mathrm{~cm}$ larg., verde na face ventral e vinosa na dorsal. Escapo ereto, ca. $17 \mathrm{~cm}$ compr.; brácteas do escapo triangulares, acuminadas, recurvadas, ca. $3,5 \mathrm{~cm}$ compr., maiores que os entrenós. Inflorescência em espiga tripla, ca. $42 \mathrm{~cm}$ compr., não secundiflora, laxa; brácteas primárias e secundárias triangulares, agudas, 1-3 cm compr.; ramos ca. 8, 10-15 cm compr. patentes; brácteas florais largo-ovadas, obtusas, 0,6-0,7 cm compr., não carenadas. Flores dísticas, sésseis; sépalas ovadas, ápice obtuso, 0,4-0,5 cm compr., não carenadas, verdes; pétalas inclusas no cálice, sem apêndices; estames inclusos.

Distribuição geográfica e habitat: Costa Rica, Panamá, República Dominicana, Colômbia, Venezuela, Suriname, Equador, Trinidad, Guiana, Peru, Bolívia e Brasil: Ceará, Bahia, Espírito Santo, Rio de Janeiro, São Paulo, Paraná e Santa Catarina (Smith \& Downs 1977). No Brasil ocorre na Floresta Pluvial Atlântica.

Material examinado: 8.III.1992, fr., A. Costa et al. $427(\mathrm{RB})$.

$\mathrm{Na}$ área ocorre com pouca freqüência como epífita nas margens do rio das Flores.

7. Tillandsia geminiflora Brongn. in Duperrey, Voy. monde 186. 1829; Smith \& Downs, Fl. Neotrop. Monogr. 14(2): 804-7, fig. 250 G-I. 1977.

Planta florida 12-20 cm alt., epífita. Folhas maleáveis, 9-12 cm compr., roseta não formando tanque; bainha reduzida, $1-1,5 \mathrm{~cm}$ larg., alva; lâmina subulada, atenuada, 0,6-1,2 cm larg., verde, indumento argênteo denso. Escapo ereto a curvo, 5,5-9 cm compr.; brácteas do escapo foliáceas, 8-3,5 cm compr., mais longas que os entrenós, verdes. Inflorescência em racemo heterotético duplo, 4-7 × 3-6 cm, globosa, densa; brácteas primárias elípticas, caudadas, 1,5-4,5 compr., verdes com nuances vinosas; ramos 6-12, eretos, 2-4 flores sendo a apical estéril; brácteas florais triangulares, acuminadas, incurvadas, 0,7-1,2 cm compr., mais curtas que as sépalas, carenadas, róseas. Flores dísticas com pedicelo curto; sépalas oblongo-lanceoladas, acuminadas, ca. $1 \mathrm{~cm}$ compr., carenadas, róseas; pétalas lineares, retusas, ca. 1,5 cm compr., rósea escura, sem apêndices; estames inclusos.

Distribuição geográfica e habitat: Paraguai, Uruguai, Argentina e Brasil: Goiás, Mato Grosso do Sul, Minas Gerais, Espírito Santo, Rio de Janeiro, São Paulo, Paraná, Santa Catarina e Rio Grande do Sul (Smith \& Downs 1977), além da Paraíba e do Distrito Federal. Floresta Pluvial Atlântica, restingas, matas de galeria dos cerrados e áreas degradadas.

Material examinado: 16.IV.1991, bot., A. Costa et al. 373 (RB); 16.IV.1991, fr., A. Costa et al. 374 (RB); 3.XII.1991, fr., A. Costa et al. 398 (RB); 26.VIII.1987, fl., M. Leitman et al. 254 (RB).

8. Tillandsia roseiflora R.Ehlers \& W.Weber, Bromelie, Sonderheft 3: 52. 1996.

Planta florida 10-14(-18) cm alt., epífita. Folhas maleáveis, 5-8(-15) cm compr., não formando tanque; bainha reduzida, $0,8-1 \mathrm{~cm}$ larg., alva; lâmina estreito-ovada, atenuada, 12-17 mm larg. no terço inferior, verde, indumento argênteo muito denso. Escapo ereto a curvo, 6-9 cm compr.; brácteas do escapo estreito-elípticas, longo-caudadas, $4,5(-8,5) \mathrm{cm}$ compr., mais longas que os entrenós, esverdeadas. Inflorescência em racemo ou raramente em racemo heterotético duplo, 2-4 $\times 2-3(-4) \mathrm{cm}$, globosa, densa; brácteas florais largo-elípticas, obtusas e apiculadas, 1,8-2,5× 1,3-1,5 cm, mais longas que as sépalas, não carenadas, róseas. Flores dísticas com pedicelo curto; sépalas estreito-elípticas, agudas e apiculadas, 1,3-1,8 cm compr., 2 carenadas e 1 não carenada, verde-alvacentas a róseas; pétalas lineares, obtusas, ca. 2,2 cm compr., albo-róseas, sem apêndices; estames inclusos. Distribuição geográfica e habitat: Rio de Janeiro. Ocorre como epífita na Floresta Pluvial Atlântica alto-montana entre 1.100-1.400 m.s.m. Material examinado: 16.IV.1991, fl., A. Costa et al. 375 (RB); 18.VI.1986, fl., G. Martinelli et al. 11753 (RB); 25.X.1986, fl., G. Martinelli et al. 11839 (RB); 8.VI.1989, fr., H. C. Lima et al. 3601 (RB); 17.7.1987, fr., S. V. A. Pessoa et al. 230 (RB); 19.VIII.1987, fl., S. V. A. Pessoa et al. 265 (RB); 1.VI.1990, fl., S. V. A. Pessoa et al. 512 (RB). 
Tillandsia roseiflora é endêmica da Floresta Pluvial Atlântica alto-montana do estado do Rio de Janeiro, ocorrendo também no Pico do Frade, município de Macaé.

9. Tillandsia stricta Sol., Bot. Mag. 37: est. 1529. 1813; Smith \& Downs, Fl. Neotrop. Monogr. 14(2): 824-6, fig. 259. 1977.

Planta florida ca. $20 \mathrm{~cm}$ alt., epífita. Folhas rígidas, $3-13 \mathrm{~cm}$ compr., não formando tanque; bainha reduzida, ca. $0,8 \mathrm{~cm}$ larg., alva; lâmina subulada, longo-atenuada, $0,7-0,9 \mathrm{~cm}$ larg., verde-clara, indumento argênteo. Escapo ereto ou curvo, 8-10 cm compr., verde; brácteas do escapo elípticas, longo-caudadas, 3-9 cm compr., mais longas que os entrenós, verdes. Inflorescência em racemo, 3-4 cm compr., oblongo-ovada, densa; brácteas florais largoovadas, obtusas e apiculadas, as inferiores caudadas, 1,5-3×1,5 cm, não carenadas, róseas. Flores polísticas, curto pediceladas; sépalas elípticas, agudas, ca. 1,2 cm compr., concrescidas por ca. $0,2 \mathrm{~cm}$, carenadas, verde-alvacentas; pétalas lineares, obtusas, ca. 1,8 cm compr., concrescidas por ca. $1 \mathrm{~cm}$, liláses, sem apêndices; estames inclusos.

Distribuição geográfica e habitat: Venezuela, Trinidad, Guyana, Suriname, Paraguai, Uruguai, Argentina e Brasil: entre a Bahia e Santa Catarina, inclusive Minas Gerais (Smith \& Downs 1977). Floresta Pluvial Atlântica baixo-montana, montana, alto-montana; Floresta Pluvial de Araucária; Floresta Pluvial dos Tabuleiros, mangue, mata de restinga, restinga e vegetação alterada. Material examinado: 4.XII.1991, fl., A. Costa et al. 407 (RB).

Ao longo de sua distribuição, suas populações podem ser ou não densas e é comum a formação de touceiras. Apresenta grande variabilidade, sobretudo, em relação ao tamanho, consistência e coloração das folhas, e número de flores na inflorescência. Ocorre como epífita pouco expressiva na área.

10. Tillandsia tenuifolia $\mathrm{L}$., Sp. Pl. 286. 1753; Smith \& Downs, Fl. Neotrop. Monogr. 14(2): 828. 1977.

Planta florida ca. $19 \mathrm{~cm}$ alt., epífita. Folhas rígidas, 3-14 cm compr., as mais externas menores, não formando tanque; bainha reduzida, $0,8-1,1 \times 0,5-1 \mathrm{~cm}$, alva; lâmina subulada, atenuada, ca. 0,3 cm larg., verdes, indumento argênteo denso. Escapo ereto, ca. 9 cm compr., verde; brácteas do escapo elípticas, caudadas, ca. 2,7 cm compr., mais longas que os entrenós, envolvendo o escapo, vinosas. Inflorescência em espiga, ca. 3,5 cm, densa; brácteas florais elípticas, agudas, incurvadas, ca. $1,7 \times 1 \mathrm{~cm}$, não carenadas, vinosas. Flores polísticas, sésseis; sépalas elípticas, agudas, ca. 1,1 cm compr., as posteriores carenadas e concrescidas por 2/3; pétalas lineares, obtusas, ca. 2,2 cm compr., alvas; estames inclusos.

Distribuição geográfica e habitat: Ocorre desde a América Central até a Argentina. No Brasil: Pará, Ceará, Paraíba até o Rio Grande do Sul (Smith \& Downs 1977). Florestas Tropicais úmidas da América do Sul e Central, Floresta Pluvial Atlântica montana, Restinga, vegetação alterada.

Material examinado: 14.VIII.1989, fl., C. M. Vieira et al. 73 (RB).

11. Vriesea altomacaensis A. F. Costa, J. Bromeliad Soc. 44(4): 159-164, fig. 6e 8. 1994.

Planta florida $0,8-1,2 \mathrm{~m}$ alt., terrestre. Folhas eretas, 0,55-1,10 m compr., formando roseta infundibuliforme; bainha oblonga, ca. 13 $\times 7,5-8 \mathrm{~cm}$, castanho-clara em ambas as faces, com uma faixa castanha escura na base; lâmina linear, aguda, ca. 4,5 cm larg., ornamentada com linhas transversais irregulares obscuras e de um verde mais escuro. Escapo ereto, $50-80 \mathrm{~cm}$ compr., verde-claro; brácteas do escapo imbricadas, eretas, as inferiores foliáceas, estreito-ovadas, acuminadas, $8-20 \mathrm{~cm}$ compr., verdes; as medianas e superiores ovadas, acuminadas, 5,5-7 cm compr., verde-amareladas. Inflorescência em racemo heterotético duplo, 35-60 cm compr., cilíndrica, densa, secundiflora; raque amarela ou verde; brácteas primárias ovadas, acuminadas, as superiores ca. $3,5 \mathrm{~cm}$ compr., as inferiores 4,5-5,5 cm compr., amarelas a verdes; ramos ca. 14, ca. $10 \mathrm{~cm}$ compr., eretos, os inferiores apresentando uma bráctea basal carenada, incurvada e estéril; brácteas florais ovadas, agudas e incurvadas, 1,6-2,5 ×1,5 cm, 
patentes, mais curtas que as sépalas, raramente carenadas em direção ao ápice, amarelas. Flores dísticas, pedicelos curvos, 0,5-0,9 cm compr.; sépalas obovadas, obtusas, ca. 2 cm compr., amarelas; pétalas estreito-obovadas, ca. $2,8 \mathrm{~cm}$ compr., concrescidas por $0,2 \mathrm{~cm}$, eretas na antese, amarelas, apêndices com ápices irregulares, ca. 0,4 cm compr.; estames inclusos. Sementes com apêndices até $3 \mathrm{~mm}$ compr. Distribuição geográfica e habitat: Rio de Janeiro. Terrestre na Floresta Pluvial Atlântica alto-montana entre 1200-1450 m.s.m. Ocorre na área em pequenas populações na Pedra Bicuda e na cumeada da Serra de São João, no caminho para a Serra dos Pirineus.

Material examinado: 16.IV.1991, fr., A. Costa et al. 369 (RB); 16.IV.1991, fr., A. Costa et al. 378 (RB); 2.XII.1991, bot., A. Costa et al. 388 (RB); 1618.XII.1992, fl., A. Costa et al. 435 (RB); 16.IV.1991, fr., A. Costa et al. 353 (RB, holótipo); XII.1990, fl., A. T. Britto s.n. (RB 291027, parátipo).

É afim à $V$. thyrsoidea Mez, da qual difere, sobretudo, pelas folhas bem mais longas e de ápice agudo e brácteas da inflorescência totalmente amarelas.

12. Vriesea arachnoidea A. F. Costa, J. Bromeliad Soc. 44(4): 159-164, fig. 9 E, 10. 1994.

Fig. 1 e

Planta florida ca. $20 \mathrm{~cm}$ alt., terrestre ou epífita. Folhas arqueadas a pendentes, formando roseta utriculosa; bainha elíptica, ca. $8 \times 4 \mathrm{~cm}$, verde com máculas densamente agrupadas formando estrias transversais, largas, irregulares e atropurpúreas; lâmina linear, atenuada, ca. $28 \times 0,5 \mathrm{~cm}$, verde com algumas máculas purpúreas. Escapo curvo, ca. 34 cm compr., verde; brácteas inferiores do escapo com base elíptica igualando os entrenós e ápice linear, longo-atenuado, ca. 12 cm compr., as superiores idênticas, porém com ápice mais curto. Inflorescência em racemo, ca. $22 \mathrm{~cm}$ compr., secundiflora, laxa; brácteas florais ovadas, acuminadas, incurvadas, ca. 2,2 cm compr., sem carena. Flores dísticas e patentes na antese, pedicelos curvos, ca. 0,6 cm compr.; sépalas elípticas, obtusas, ca. 2,4 cm compr., carenadas; pétalas lineares, ca. 3,5 cm compr., concrescidas por ca. 0,4 cm, eretas na antese, verdes, apêndices obovados e obtusos, ca. 0,8 cm compr.; estames exsertos.

Distribuição geográfica e habitat: Minas Gerais e Rio de Janeiro. Floresta Pluvial Atlântica alto-montana.

Material examinado: 2.II.1992, fr., A. Costa et al. 425 (RB, parátipo); 16-18.XII.1992, fl., A. Costa et al. 445 (RB, holótipo).

Vriesea arachnoidea é afim a $V$. flammea L.B.Sm. dela diferindo sobretudo, pela inflorescência secundiflora, flores dísticas e pelas brácteas florais ovadas com ápice acuminado e incurvado. Ocorre em reduzidíssima população em um trecho de mata nebular a cerca de 1.350 m.s.m. no Sítio Hum Baccus, na região de Macaé de Cima. Forma touceiras sobre o folhiço, mas alguns indivíduos foram observados como epífitos. Ocorre também na região vizinha do Pico do Frade, Macaé. É interessante notar, entretanto, a ocorrência disjunta da espécie na Serra do Brigadeiro, em Araponga, Minas Gerais.

13. Vriesea atra Mez, in Mart., Eichler \& Urban, Fl. bras. 3(3): 543, fig. 101. 1894; Smith \& Downs, Fl. Neotrop. Monogr. 14(2): 1122. 1977.

Planta florida ca. $1 \mathrm{~m}$ alt., epífita. Folhas suberetas, 64-70 cm compr., formando roseta infundibuliforme ampla; bainha elíptica, ca. 13 $\times 12 \mathrm{~cm}$, castanha; lâmina linear, acuminada, 8-9 cm larg., verde com linhas transversais de um verde mais escuro, máculas atropurúreas na face dorsal entre a lâmina e a bainha. Escapo ereto, 40-84 cm compr., verde-escuro, recoberto por substância gelatinosa transparente; brácteas inferiores do escapo foliáceas, as medianas triangulares, acuminadas, imbricadas, 5-6 cm compr., mais longas que os entrenós, verdes com máculas atropurpúreas, as superiores ovadas, obtusas e apiculadas, 3,5-4 cm compr., pouco mais longas que os entrenós, castanhas, margem verde com máculas atropurpúreas. Inflorescência em racemo, 22-25 × 8-9 cm, oblonga, densa, raque levemente geniculada, recoberta por substância gelatinosa incolor e inodora; brácteas florais largo-ovadas com aurículas decurrentes na base, obtusas, ca. 3,5 
$\times 3,5 \mathrm{~cm}$, não carenadas, castanhas, margem verde com máculas atropurpúreas. Flores dísticas, patentes a reflexas, pedicelos robustos, ca. $1 \mathrm{~cm}$ compr.; sépalas ovadas, retusas, ca. $3 \mathrm{~cm}$ compr.; pétalas obovadas, obtusas, ca. 4,8 cm compr., eretas, apêndices não observados; estames inclusos.

Distribuição geográfica e habitat: Rio de Janeiro (Smith \& Downs 1977). Floresta Pluvial Atlântica alto-montana.

Material examinado: 16-18.XII.1992, fr., A. Costa et al. 436 (RB).

Algumas espécies pertencentes à seção Xiphion, tais como V. atra, V. platynema Gaudich., V. regnellii Mez, V. tijucana E. Pereira, $V$. fenestralis Linden \& André, $V$. jonghei (K. Koch) E. Morren, V. gamba F. J. Müll. e V. bituminosa Wawra, as quais constituem um grupo filogeneticamente relacionado (Costa 2002), merecem estudos populacionais objetivando uma melhor circunscrição específica (Costa 1993).

14. Vriesea bituminosa Wawra, Österr. Bot. Z. 12: 347. 1862; Smith \& Downs, Fl. Neotrop. Monogr. 14(2): 1130, fig. 366-A. 1977.

Fig. 1b

Planta robusta, florida de 1-1,8 m alt., epífita, raramente terrestre. Folhas suberetas, 60-90 cm compr., formando roseta infundibuliforme densa e ampla; bainha ovada a largo-elíptica, 12-18 × 10-14 cm, castanha nas duas faces; lâmina linear, plicada, obtusa e acuminada, 7-9 cm larg., verde com linhas transversais irregulares de cor verde mais escura visíveis apenas em material vivo, geralmente apresentando no ápice uma mácula atropurpúrea de até $3 \mathrm{~cm}$ de diâmetro. Escapo ereto, 60-80 cm compr., robusto, verde a castanho-esverdeado; brácteas do escapo eretas, mais longas que os entrenós, as inferiores ovadas, acuminadas, $7-17 \mathrm{~cm}$ compr., verdes, as medianas ovadas, acuminadas, recurvadas, 5,5-8 cm compr., verdes, as superiores ovadas, agudas a acuminadas, 4,5-5 cm compr., verdes a castanhas, ou verdes com ápice castanhoescuro. Inflorescência em racemo, 40-85 cm, não secundiflora, laxa, recoberta por substância gelatinosa e fortemente odorífera; brácteas florais largo-ovadas, agudas, as da base da inflorescência ca. 4,5 cm compr., as do ápice 3-3,5 × $3 \mathrm{~cm}$, com aurículas decurrentes na base, apresentando nervuras salientes que se prolongam dando uma aparência costada à raque, verdes, de textura lisa a finamente nervada em direção ao ápice. Flores dísticas, reflexas na antese, pedicelo robusto; sépalas elípticas, obtusas, ca. 4 cm compr., verdes; pétalas obovadas, obtusas, carnosas, ca. $6 \mathrm{~cm}$ compr., concrescidas por ca. $0,3 \mathrm{~cm}$, eretas, creme com linhas atropurpúreas, tornando-se totalmente vinosas após a antese, apêndices com ápice agudo irregular, ca. 1,5 cm compr.; estames inclusos.

Distribuição geográfica e habitat: Minas Gerais, Rio de Janeiro e São Paulo (Smith \& Downs 1977), Espírito Santo e Bahia. Sua ocorrência na Venezuela e no Ceará (Smith \& Downs 1977) precisa ser confirmada. Floresta Pluvial Atlântica montana e alto-montana. A espécie é bem distribuída na área, podendo ser encontrada como epífita ou terrestre, tanto em formações secundárias, quanto naquelas bem preservadas.

Material examinado: 6.XII.1988, bot., A. Costa et al. 210 (RB); 6.III.1991, fr., A. Costa et al. 354 (RB); 16.IV.1991, fr., A. Costa et al. 371 (RB); 1618.XII.1992, fl., A. Costa et al. 440 (RB); 25.V.1987, fl., G. Martinelli et al. 12043 (RB).

A presença de uma substância gelatinosa fortemente odorífera, que recobre toda a inflorescência, e sua aparência betuminosa são suas principais características.

15. Vriesea carinata Wawra, Österr. Bot. Z. 12: 349. 1862; Smith \& Downs, Fl. Neotrop. Monogr. 14(2): 1218, fig. 397 A. 1977.

Planta florida ca. $23 \mathrm{~cm}$ alt., epífita. Folhas suberetas, ca. $18 \mathrm{~cm}$ compr., formando roseta infundibuliforme; bainha elíptica, ca. 4,5 $\times 2 \mathrm{~cm}$, alvacenta; lâmina linear, aguda, apiculada, 1,2-2 cm larg., verde-clara. Escapo ereto a curvo, ca. 17 cm compr., verde-claro; brácteas do escapo estreito-ovadas, atenuadas, ca. 2 cm compr., igualando o entrenó ou pouco 


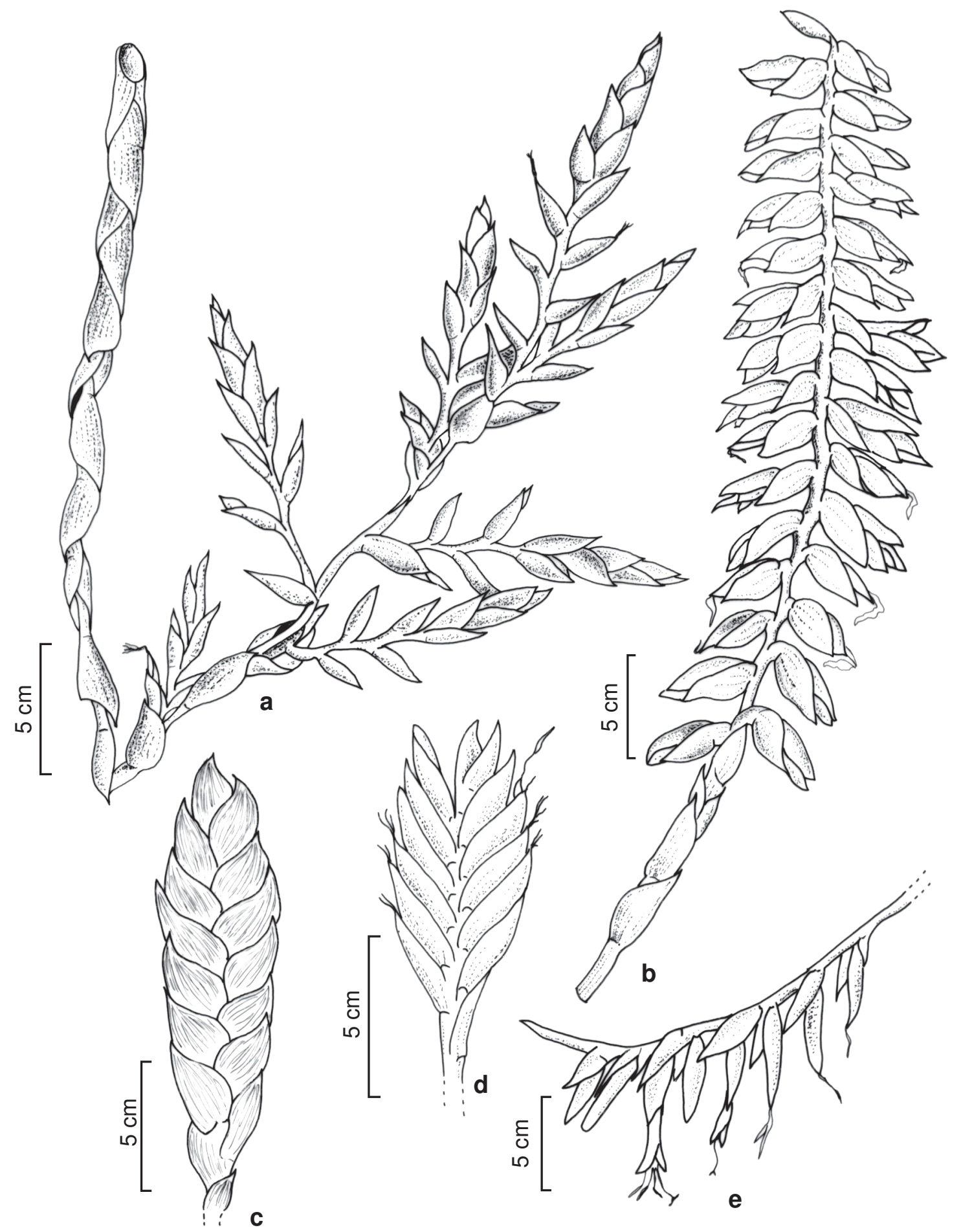

Figura 1 - Inflorescências: a. Vriesea triligulata (Costa 351); b. V. bituminosa (Costa 371); c. V. heterostachys (Costa 364); d. V. paraibica (Costa 368); e. V. arachnoidea (Costa 425). 
mais curtas, verde-alvacentas. Inflorescência em racemo, ca. $3,5 \times 5 \mathrm{~cm}$, quadrada a oblonga, densa, não secundiflora; raque fracamente geniculada; brácteas florais ovadas, agudas, incurvadas, 2,5-3 × 1-1,2 cm, igualando as sépalas, carenadas, não infladas, vermelhas com ápice amarelo. Flores dísticas, eretas a patentes na antese, pedicelo ca. $0,4 \mathrm{~cm}$ compr.; sépalas elípticas, obtusas, ca. 2,5 cm compr., carenadas, amarelas a verdes; pétalas lineares, ca. $5 \mathrm{~cm}$ compr., eretas, amarelas com ápice verde, apêndices arredondados, ca. 0,6 cm compr.; estames exsertos.

Distribuição geográfica e habitat: Espírito Santo, Rio de Janeiro, São Paulo, Paraná, Santa Catarina e Rio Grande do Sul (Smith \& Downs 1977). Sua ocorrência na Bahia (Smith \& Downs 1977) não foi confirmada e não são conhecidos outros espécimes de herbário para este estado (Costa 2002). Pode ser encontrada desde o nível do mar, na restinga e na Floresta Pluvial Atlântica baixo-montana e montana até ca. de 1.000 m.s.m.

Material examinado: 7.VII.1991, fl., A. Costa et al. 382 (RB); 1-4.II.1991, bot., A. Costa et al. 416 (RB); 8.III.1992, bot., A. Costa et al. 428 (RB).

Ao longo de sua área de distribuição, algumas variações podem ser observadas, tais como a forma da inflorescência, que pode ser quadrada a oblonga, e as flores que variam em número, desde 4 até 16 . Na região de Macaé de Cima, V. carinata apresenta-se pouco expressiva, ocorrendo em pequena população epífita nas margens do rio Macaé.

16. Vriesea flammea L.B.Sm., Arq. Bot. Estado São Paulo II. 1: 59, fig. 79. 1941; Smith \& Downs, Fl. Neotrop. Monogr. 14(2): 1246, fig. 411. 1977.

Planta florida ca. $38 \mathrm{~cm}$ alt., epífita, estolonífera. Folhas suberetas, $20-23 \mathrm{~cm}$ compr., formando roseta utriculosa; bainha ovada, 5,5-6 $\times 4 \mathrm{~cm}$, atropurpúrea; lâmina linear, aguda, ca. $0,5 \mathrm{~cm}$ larg., verde com máculas atroprupúreas na base. Escapo ereto, ca. $25 \mathrm{~cm}$ compr., vinoso; brácteas do escapo ovadas, caudadas, 2,5-8 cm compr., mais longas que os entrenós, vermelhas com ápice verde. Inflorescência em racemo, ca. $6 \mathrm{~cm}$ compr., não secundiflora, densa; brácteas florais oblongo-lanceoladas, agudas e levemente incurvadas, $2,5-2,8 \times 1,4 \mathrm{~cm}$, não carenadas, vermelhas. Flores eretas, polísticas, pedicelos robustos, $0,4 \mathrm{~cm}$ compr.; sépalas elípticas, obtusas, 1,8-2 cm compr., não carenadas, esverdeadas; pétalas lineares, obtusas, emarginadas, ca. 3,3 cm compr., eretas, alvas, apêndices lineares obtusos, ca. $0,8 \mathrm{~cm}$ compr.; estames exsertos.

Distribuição geográfica e habitat: São Paulo, Paraná e Santa Catarina (Smith \& Downs 1977), Pernambuco, Bahia, Rio de Janeiro e Rio Grande do Sul. Espécie heliófila e epífita nas ramificações terminais das árvores na Floresta Pluvial Atlântica baixo-montana e mais raramente montana. Pode também se apresentar rupícola em afloramentos graníticos próximos ao mar.

Material examinado: I.1994, fl., L. Chedier \& M. Nadruz s.n. (RB 309183).

17. Vriesea garlippiana Leme, J. Bromeliad Soc. 47(3): 99-102. 1997.

Planta florida até ca. 1,4 m alt., epífita. Folhas eretas, formando roseta infundibuliforme; bainha ovada, 1,5-1,7×11-12 cm, atropurpúrea próximo à base; lâmina linear, plicada, aguda a obtusa, apiculada, 8-9 cm larg., verde com linhas irregulares transversais de um verde mais escuro e mácula castanha arredondada no ápice. Escapo ereto, 45-60 cm compr., verde a vermelho; brácteas inferiores do escapo foliáceas, as superiores ovadas, agudas e apiculadas, 5-8 cm compr., igualando ou mais longas que os entrenós, eretas, vermelhas. Inflorescência em racemo heterotético duplo, 50-60 cm compr., ampla, secundiflora na antese, laxa, raque vermelha; brácteas primárias ovadas a largo-ovadas, agudas e apiculadas, 3-7 cm compr., mais curtas que os pedúnculos dos ramos, vermelhas; ramos 15$22 \mathrm{~cm}$ compr., os basais apresentando 3 brácteas estéreis na base e os apicais apresentando 1 ou 2 ; brácteas florais elíptico-ovadas a suborbiculadas, obtusas, incurvadas, 2,5-3×2-2,5 cm, mais curtas que as sépalas, as basais carenadas, vermelhas. 
Flores dísticas, pedicelos 7-9 mm compr.; sépalas elípticas, obtusas, emarginadas, 2,1-2,3 cm compr., esverdeadas na base e amarelas no ápice; pétalas lineares, ca. 3,3 cm compr., eretas na antese, amarelas, apêndices truncados e denteados, ca. 0,5 cm compr.; estames exsertos. Sementes com apêndice apical até $3 \mathrm{~mm}$ compr. Distribuição geográfica e habitat: Rio de Janeiro. Floresta Pluvial Atântica alto-montana. Até o momento, só é conhecida a coleta do tipo (Leme 1997).

Material examinado: 10.XI.1996, fl., E. M. C. Leme et al. 3582 (HB, holótipo).

18. Vriesea heterostachys (Baker) L.B.Sm., Phytologia 19: 289. 1970; Smith \& Downs, Fl. Neotrop. Monogr. 14(2): 1216, fig. 395 A-B. 1977.

Fig. $1 \mathrm{c}$

Planta florida $30-50 \mathrm{~cm}$ alt., epífita. Folhas suberetas, $20-50 \mathrm{~cm}$ compr., formando roseta infindibuliforme; bainha elíptica a levemente obovada, $8-13 \times 5-6 \mathrm{~cm}$, geralmente alvacenta, raro vinosa; lâmina oblanceolada, acuminada, raro obtusa, 2,5-3,5 cm larg., verde. Escapo flexuoso a ereto, 15-27 cm compr., verde; brácteas do escapo elípticas, ovadas ou obovadas, agudas e apiculadas, $2,8-4 \mathrm{~cm}$ compr., mais longas que os entrenós, infladas, verdes; as superiores geralmente ovadas, assemelhando-se às brácteas florais . Inflorescência em racemo, 15-20×4-5,5 cm, oblonga, densa, apresentando ca. 2 brácteas florais estéreis no ápice, não secundiflora; raque fracamente ou não geniculada; brácteas florais ovadas a largo-ovadas, agudas e fortemente incurvadas, raro obtusas, margem formando forte curva, 3,5-4,5 ×3,4 cm, mais longas que as sépalas, carenadas em direção ao ápice, infladas, imbricadas por $1 / 3$ da sua largura, vermelho-alaranjadas às vezes com nuances verdes. Flores eretas, dísticas, pedicelo ca. 0,2 cm compr.; sépalas elípticas, agudas, ca. $3,3 \mathrm{~cm}$ compr., geralmente não carenadas mas podendo, uma delas, apresentar-se carenada; pétalas lineares, ca. $4,5 \mathrm{~cm}$ compr., concrescidas por ca. $0,2 \mathrm{~cm}$, eretas, amarelas com ápice verde, apêndices obovados, obtusos, ca. $1 \mathrm{~cm}$ compr.; estames exsertos.
Distribuição geográfica e habitat: Minas Gerais, Espírito Santo, Rio de Janeiro, São Paulo (Smith \& Downs 1977) e Paraná. Floresta Pluvial Atlântica montana.

Material examinado: 16.IV.1991, bot., A. Costa et al. 364 (RB); 16.IV.1991, bot., A. Costa et al. 366 (RB); 3.XII.1991, bot., A. Costa et al. 391 (RB); 3.XII.1991, bot., A. Costa et al. 393 (RB); 2.II.1992, fl., A. Costa et al. 418 (RB); 2.II.1992, fl., A. Costa et al. 419 (RB); 8.III.1992, fl., A. Costa et al. 430 (RB); 15.VIII.1993, fl., C. M. Vieira \& L. C. Gurken 349 (RB); 14.VII.1992, fl., M. Nadruz et al. 747 (RB).

$\mathrm{Na}$ área em estudo $V$. heterostachys é bastante freqüente, ocorrendo como epífita no interior da mata bem preservada, assim como em áreas secundárias, formando ou não touceiras. Um dos complexos de espécies que pode ser destacado no gênero Vriesea é o que envolve $V$. heterostachys, $V$. inflata (Wawra) Wawra e V. modesta Mez. Estas espécies seriam diferenciadas basicamente pela forma da inflorescência e das brácteas florais. Entretanto, a grande variação destes caracteres dentro de uma mesma espécie e entre as espécies torna difícil a delimitação entre elas. O problema é agravado pela simpatria de muitas populações e pelas flores apresentarem morfologia semelhante.

19. Vriesea hieroglyphica (Carrière) E. Morren, Ill. Hort. 31: 41, est. 514. 1884; Smith \& Downs, Fl. Neotrop. Monogr. 14(2): 1146, fig. 372 H-I. 1977.

Planta robusta, florida ca. $1 \mathrm{~m}$ alt., epífita. Folhas suberetas, 0,45-1 m compr., formando roseta infundibuliforme; bainha largo-elíptica, ca. $9 \times 12 \mathrm{~cm}$, atropurpúrea na face dorsal e castanha na face ventral; lâmina linear, aguda a obtusa, apiculada, 5-9 cm larg., verde com bandas transversais largas irregulares atropurpúreas na face dorsal e verde mais escuro na face ventral. Escapo ereto, ca. $60 \mathrm{~cm}$ compr.; brácteas inferiores do escapo foliáceas, as medianas com metade inferior ovada e metade superior triangular, atenuadas, ca. $11 \mathrm{~cm}$ compr., as superiores ovadas, acuminadas. Inflorescência em racemo heterotético duplo, secundiflora, densa, toda verde com aspecto lustroso; 
brácteas primárias ovadas, agudas a acuminadas, ca. $3,5 \times 2,5 \mathrm{~cm}$, de mais curtas a igualando os pedúnculos dos ramos; ramos 17$24 \mathrm{~cm}$ compr., eretos, pedúnculo dos ramos com 4,5-12 cm compr., apresentando 1-3 brácteas estéreis, aquele do ramo terminal com até 5 brácteas estéreis; brácteas florais ovadas, agudas e incurvadas, $1,8-2,8 \times 2 \mathrm{~cm}$, não carenadas a nitidamente carenadas em direção ao ápice, eretas a fracamente secundas. Flores dísticas, com pedicelos robustos, ca. $1 \mathrm{~cm}$ compr.; sépalas elípticas, raramente um pouco assimétricas, agudas, 2,3-2,5 cm compr., não carenadas; pétalas obovadas, ca. 3,8 cm compr., concrescidas por ca. $5 \mathrm{~mm}$, eretas, amarelas, apêndices com ápice longamente fendido, ca. $1 \mathrm{~cm}$ compr.; estames inclusos. Sementes com apêndice apical até $3 \mathrm{~mm}$ compr.

Distribuição geográfica e habitat: Espírito Santo, Rio de Janeiro, São Paulo e Paraná (Smith \& Downs 1977). Floresta Pluvial Atlântica montana até ca. 500 m.s.m., ocorrendo como epífita ou rupícola no interior da mata, junto a córregos e rios.

Material examinado: 2.II.1992, fl., A. Costa et al. 421 (RB); 18.I.1887, fl., A. F. Glaziou 16468 (P, foto).

Devido à ornamentação bastante atrativa da folhagem, as populações naturais de $V$. hieroglyphica vêm sofrendo, há vários anos, forte impacto diante da extração seletiva com fins comerciais. Não é conhecida a população da espécie na área, sendo cultivada nos jardins da região. Ocorre em altitudes mais baixas, nas matas do município vizinho de Silva Jardim, segundo informações colhidas com moradores locais.

20. Vriesea hydrophora Ule, Arq. Mus. Nac. Rio de Janeiro 10: 189. 1899; Smith \& Downs, Fl. Neotrop. Monogr. 14(2): 1151. 1977.

Planta robusta, florida ca. 1,2 m alt., epífita. Folhas eretas, 85-90 cm compr., formando roseta infundibuliforme ampla; bainha elíptica, 23-25 × 12-15 cm, castanhoescura; lâmina linear, obtusa e apiculada, ca. 9 cm larg., verde com estrias transversais irregulares de um verde mais escuro. Escapo ereto, ca. $50 \mathrm{~cm}$ compr., verde-lustroso; brácteas inferiores do escapo foliáceas, 18-
$24 \mathrm{~cm}$ compr., verdes, as medianas com a metade inferior dilatada e a metade superior oblonga, obtusas e apiculadas, verdes, as superiores elípticas, acuminadas e apiculadas, ca. $9 \mathrm{~cm}$ compr., verdes. Inflorescência em racemo heterotético duplo, ca. $80 \mathrm{~cm}$, secundiflora, toda verde com aspecto lustroso, densa; brácteas primárias inferiores semelhantes às brácteas superiores do escapo, as superiores largo ovadas, agudas e apiculadas, 4-5 cm compr., igualando o pedúnculo dos ramos; ramos 10-15, 30-35 cm compr., eretos, apresentando uma bráctea estéril na base; brácteas florais ovadas, agudas e incurvadas, apículo, quando presente, diminuto, 3-3,5×3,4 cm, carenadas em direção ao ápice, mais curtas que as sépalas e não secundas com as flores, verdes. Flores dísticas, suberetas a patentes, pedicelo robusto, ca. $1 \mathrm{~cm}$ compr.; sépalas elípticas, agudas, 3$4 \mathrm{~cm}$ compr., não carenadas, verdes; pétalas obovadas, ca. $4 \mathrm{~cm}$ compr., concrescidas por ca. 0,6 cm, eretas, amarelo-pálido, apêndices fendidos e irregulares, ca. 0,9 cm compr.; estames inclusos. Sementes com apêndices apicais até $3 \mathrm{~mm}$ compr.

Distribuição geográfica e habitat: Rio de Janeiro (Smith \& Downs 1977) e Espírito Santo. Ocorre na Floresta Pluvial Atlântica montana como epífita e na alto-montana também como terrestre.

Material examinado: 6.XII.1998, bot., A. Costa et al. 211 (RB); 8.III.1992, fl., A. Costa et al. 431 (RB); 22.I.1994, fr., C. M. Vieira \& L. C. Gurken 513 (RB).

A semelhança citada por Ule (1899) em relação a $V$. hieroglyphica, não é tão grande quanto sua afinidade com $V$. pabstii McWilliams \& L.B.Sm. Porém, esta última apresenta a inflorescência menos ramificada e de dimensões menores. Estas espécies apresentam todas as brácteas de cor verde clara com aspecto lustroso.

21. Vriesea inflata (Wawra) Wawra, It. Sax.Cob. 1: 161. 1883; Smith \& Downs, Fl. Neotrop. Monogr. 14(2): 1214-5, fig. 394 D. 1977.

Planta florida ca. $35 \mathrm{~cm}$ alt., epífita. Folhas suberetas, 30-50 cm compr., formando 
roseta infundibuliforme; bainha elíptica, 10-13 $\times 5-6 \mathrm{~cm}$, alvacenta; lâmina linear, acuminada, $2-2,5 \mathrm{~cm}$ larg., verde. Escapo ereto ou flexuoso, 15-30 cm compr., verde-claro; brácteas inferiores do escapo oblongas, acuminadas, ca. $8 \mathrm{~cm}$ compr., mais longas que os entrenós, as medianas ovadas a largoelípticas, obtusas a acuminadas, 2,7-3 cm compr., as superiores largo-ovadas, agudas e apiculadas, ca. $3 \mathrm{~cm}$ compr., verdes. Inflorescência em racemo, $12-15 \times 6-7 \mathrm{~cm}$, elíptica ou ovada, não secundiflora, densa; brácteas florais de ovadas a largo-ovadas, agudas, levemente incurvadas, às vezes apiculadas, margem formando curva suave, 4 $5 \times 3-4 \mathrm{~cm}$, carenadas em direção ao ápice, mais longas que as sépalas, infladas, imbricadas por $1 / 2$ de sua largura, sendo 2 ou 3 estéreis na base da inflorescência. Flores dísticas, eretas, pedicelo ca. 0,4 cm compr.; sépalas elípticas, agudas a obtusas, 2,3-2,5 cm compr., não carenadas ou com carena em 1 ou 2 sépalas por flor; pétalas lineares, $4,5 \mathrm{~cm}$ compr., concrescidas por ca. 0,3 cm compr., amarelas, apêndices obtusos e irregulares; estames exsertos.

Distribuição geográfica e habitat: Espírito Santo, Rio de Janeiro, São Paulo e Paraná (Smith \& Downs 1977) e Santa Catarina (Reitz 1983). Floresta Pluvial Atlântica montana.

Material examinado: 3.XII.1991, bot., A. Costa et al. 392 (RB); 24.VIII.1986, fr., M. Leitman 139 (RB); 17.VIII.1987, bot., S. V. A. Pessoa et al. 226 (RB).

Vriesea inflata apresenta, no Estado do Rio de Janeiro, formas de difícil delimitação com $V$. heterostachys no que tange à morfologia da inflorescência (Costa 1993).

22. Vriesea longicaulis (Baker) Mez, in Mart., Eichler \& Urban, Fl. bras. 3(3): 542, 1894; Smith \& Downs, Fl. Neotrop. Monogr. 14(2): 1113, fig. 358 E-F. 1977.

Planta florida ca. $80 \mathrm{~cm}$ alt., epífita. Folhas arqueadas, 43-49 cm compr., formando roseta infundibuliforme; bainha elíptica, $10-11 \times 4 \mathrm{~cm}$, alvacenta na face ventral e castanho-escura na face dorsal; lâmina linear, aguda e apiculada, 2,5-3 cm larg., verde.
Escapo ereto, ca. $70 \mathrm{~cm}$ compr.; brácteas inferiores do escapo foliáceas, medianas e superiores ovadas, agudas, ca. 6,5 cm compr., mais longas que os entrenós, envolvendo o escapo, castanhas, lisas e quebradiças, com o terço superior estramíneo. Inflorescência em racemo, ca. $14 \mathrm{~cm}$, geralmente secundiflora na antese, densa; raque geniculada; brácteas florais ovadas, obtusas, 3-4 × 2,5 cm, não carenadas, mais longas que as sépalas, castanho-avermelhadas, lisas e quebradiças, com margem e ápice estramíneos. Flores dísticas, suberetas, pedicelo ca. 0,4 cm compr.; sépalas elípticas, fracamente assimétricas, obtusas, ca. 2,7 cm compr.; pétalas obovadas, ca. 3,5 cm compr., eretas, amarelas, apêndices liguliformes agudos, ca. $1 \mathrm{~cm}$ compr.; estames inclusos, na antese assumindo posição funcionalmente inferior na corola.

Distribuição geográfica e habitat: Minas Gerais, Espírito Santo, Rio de Janeiro, São Paulo e Santa Catarina (Smith\& Downs 1977). Floresta Pluvial Atlântica montana e altomontana. Na região de Macaé de Cima foram observados indivíduos solitários epífitos nas partes baixas dos troncos das árvores nas matas de encosta e nebulares, podendo neste último ambiente formar populações terrestres. Material examinado: 24.IV.1994, fl., C. M. Vieira \& L. C. Gurken 579 (RB); 15.IX.1991, fr., E. L. Jacques et al. 237 (RB); 1.V.2001, fl., J. V. Barros \& M. Nadruz 4 (RB).

Vriesea longicaulis é muitas vezes confundida, em coleções de herbário, com $V$. longiscapa Ule. No entanto, é bem definida pelas brácteas do escapo e florais castanhas, lisas e quebradiças e com ápice estramíneo.

23. Vriesea longiscapa Ule, Ber. Deutsch. Bot. Ges. 18: 323. 1900; Mez, in Engler, Pflanzenr. 4 (32): 393. 1934-35; Smith \& Downs, Fl. Neotrop. Monogr. 14(2): 1149, fig. 374 D-F. 1977.

Planta florida 0,6-1,2 m alt., epífita. Folhas arqueadas, 36-63 cm compr., formando roseta infundibuliforme; bainha elíptica, 10-12 ×6 cm, de verde alvacenta em ambas as faces a castanha na face dorsal; 
lâmina linear, acuminada, 2,5-3,5 cm larg., verde, levemente discolor. Escapo ereto, 60 $98 \mathrm{~cm}$ compr., verde; brácteas inferiores do escapo foliáceas; medianas ovadas a estreitoovadas, agudas a geralmente acuminadas, 4,5$8 \mathrm{~cm}$ compr., imbricadas, eretas, verdes, textura lisa passando a rugosa, tornando-se estramíneas com o desenvolvimento, as superiores ovadas a largo-ovadas, $3-4,5 \mathrm{~cm}$ compr., imbricadas a mais curtas que os entrenós, verdes, tornando-se estramíneas. Inflorescência em racemo, 8-26 cm compr., secundiflora na antese, densa, 11 a 22 flores, raque fracamente geniculada; brácteas florais ovadas a largo-ovadas, agudas, $2-3 \times 2,5 \mathrm{~cm}$, mais curtas ou mais longas que as sépalas, às vezes carenadas em direção ao ápice, verdes e lisas quando jovens, passando a estramíneas na frutificação. Flores dísticas, eretas ou suberetas, pedicelo $0,5-0,7 \mathrm{~cm}$ compr.; sépalas largo-elípticas, obtusas, 2,5-2,7 cm compr., não carenadas, amarelas; pétalas obovadas, ca. 3 $\mathrm{cm}$ compr., carnosas, amarelas, apêndices triangulares, agudos, ca. $1 \mathrm{~cm}$ compr.; estames inclusos, na antese assumindo posição funcionalmente inferior na corola.

Distribuição geográfica e habitat: Espírito Santo e Rio de Janeiro (Smith \& Downs 1977) e São Paulo. Floresta Pluvial Atlântica montana. $\mathrm{Na}$ região de Macaé de Cima, V. longiscapa distribui-se, sobretudo, no interior das matas, onde indivíduos solitários formam expressivas populações epífitas sobre troncos e lianas.

Material examinado: 16.IV.1991, fr., A. Costa et al. 362 (RB); 3.XII.1991, fr., A. Costa et al. 397 (RB); 5.XII.1991, fl., A. Costa et al. 414 (RB); 10.IV.1994, fl., C. M. Vieira \& L. C. Gurken 577 (RB); 10.X.1986, fl., G. Martinelli et al. 11780 (RB); 20.V.1987, bot., G. Martinelli et al. 12045 (RB); 5.X.1987, fl., G. Martinelli et al. 12247 (RB); 26.IV.1988, bot./fr., G. Martinelli et al. 12411 (RB); I.1900, bot., Ule 4956 (B, holótipo).

É uma espécie bem definida pelas brácteas florais geralmente estramíneas e inflorescência que desde cedo começa a tornar-se secundiflora. Alguns exemplares provenientes de outras localidades apresentam a inflorescência com 1 ou 2 ramos (Costa 1993).
24. Vriesea paraibica Wawra, It. Sax.-Cob. 1: 160, est. 33, fig. B, est. 36, fig. B. 1883; Smith \& Downs, Fl. Neotrop. Monogr. 14(2): 1221, fig. 397-C. 1977; Leme, J. Bromeliad Soc. 36(5): 217-219.1986.

Fig. $1 \mathrm{~d}$

Planta florida 30-40 cm alt., epífita. Folhas suberetas, $20-40 \mathrm{~cm}$ compr., formando roseta infundibuliforme; bainha elíptica, 6-11 $\times 5-6 \mathrm{~cm}$, verde a alvacenta; lâmina linear, aguda e apiculada, 2,5-3 cm larg., verde. Escapo ereto, 18-26 cm compr., verde; brácteas do escapo ovadas a elípticas, obtusas, raro agudas, apiculadas, 2,5-3,5 cm compr., mais longas que os entrenós, verde-claras, as superiores semelhantes às brácteas florais. Inflorescência em racemo, 9-11 × 4,5-6 cm, oblonga, não secundiflora, densa, geralmente apresentando ca. 2 brácteas estéreis no ápice; raque fracamente geniculada; brácteas florais ovadas, agudas, fracamente incurvadas, em geral apresentando um apículo diminuto, 3,5$4,5 \times 2,2-2,6 \mathrm{~cm}$, mais longas que as sépalas, não infladas, carenadas em direção ao ápice, vermelhas quando das flores jovens e com ápice esverdeado na maturidade. Flores dísticas, sub-eretas na antese, pedicelo ca. $0,2 \mathrm{~cm}$ compr.; sépalas elípticas a estreito-ovadas, agudas, 3-3,5 cm compr., geralmente sendo 2 carenadas e 1 não carenada, amareloesverdeadas; pétalas lineares, ca. $5 \mathrm{~cm}$ compr., concrescidas por $0,2-0,3 \mathrm{~cm}$, eretas, amarelas, apêndices agudos com ápice irregular, 0,8$0,9 \mathrm{~cm}$ compr.; estames exsertos.

Distribuição geográfica e habitat: Rio de Janeiro e Minas Gerais (Smith \& Downs 1977). Floresta Pluvial Atlântica montana e altomontana. Na região de Macaé de Cima, $V$. paraibica ocorre em populações reduzidas e esparsas formadas por indivíduos epífitos solitários ou formando pequenas touceiras.

Material examinado: 16.IV.1991, fl., A. Costa et al. 368 (RB); 16.IV.1991, bot., A. Costa et al. 379 (RB); 16.IV.1991, fl., A. Costa et al. 380 (RB); 7.VII.10991, fr., A. Costa et al. 383 (RB); 3.XII.1991, fr., A. Costa et al. 394 (RB); 3.XII.1991, fl., A. Costa et al. 395 (RB); 1.II.1992, fl., A. Costa et al. 424 (RB); 5.III.1994, fl., C. M. Vieira \& L. C. Gurken 558 (RB). 
Muitas coleções de herbários pertencentes a diferentes táxons, foram identificadas como $V$. morreniana E. Morren. No entanto, este é um híbrido artificial o qual não ocorre na natureza (Morren 1882; Costa 1997, 2002).

25. Vriesea philippocoburgii Wawra, Österr. Bot. Z. 30: 219. 1880; Smith \& Downs, Fl. Neotrop. Monogr. 14(2): 1240, fig. 407 A-E. 1977.

Planta florida ca. 1,5 m alt., epífita. Folhas suberetas, 57-62 cm compr., formando roseta infundibuliforme; bainha elíptica, 13-15 $\times 9 \mathrm{~cm}$, castanha com manchas vinosas na parte superior; lâmina linear, obtusa e apiculada, 4,5-5 cm larg., verde com ápice purpúreo. Escapo ereto, ca. $20 \mathrm{~cm}$ compr.; brácteas do escapo foliáceas, acuminadas, 8 $17 \mathrm{~cm}$ compr., maiores que os entrenós, verdes com ápice purpúreo. Inflorescência em racemo heterotético duplo ou triplo, ca. $70 \times$ $30 \mathrm{~cm}$, laxa; brácteas primárias ovadas, acuminadas, 3-7 cm compr.; ramos 17, 16-27 cm compr., 1-3 brácteas estéreis na base; brácteas florais ovadas, agudas, incurvadas, $2,5-2,8 \times 1,3-1,5 \mathrm{~cm}$, carenadas ou não, vermelhas, secundas com as flores. Flores dísticas, suberetas a patentes, pedicelo ca. 5 mm compr.; sépalas obovadas, agudas, $2,8 \mathrm{~cm}$ compr., não carenadas, amarelas; pétalas lineares, obtusas, ca. $3,3 \mathrm{~cm}$ compr., amarelas, eretas, apêndices lineares, ca. $8 \mathrm{~mm}$ compr.; estames exsertos.

Distribuição geográfica e habitat: Rio de Janeiro ao Rio Grande do Sul (Smith \& Downs 1977). Floresta Pluvial Atlântica montana, altomontana e campos de altitude.

Material examinado: II.1995, fl., A. Costa et al. 507 (RB); 31.VII.1993, fl., C. M. Vieira \& L. C. Gurken $336(\mathrm{RB})$.

26. Vriesea procera (Mart. ex Schult. \& Schult. f.) Wittm., Bot. Jahrb. Syst. 13 (Beibl. 29): 21. 1891; Smith \& Downs, Fl. Neotrop. Monogr. 14(2): 1205-9, fig. 390 G, 391 A-C. 1977.

Planta florida $60-85 \mathrm{~cm}$ alt., epífita. Folhas eretas a recurvadas, $15-20 \mathrm{~cm}$ compr., formando roseta infundibuliforme; bainha elíptica, ca. $6,5 \times 3,5 \mathrm{~cm}$, castanha em ambas as faces; lâmina linear, acuminada, ca. 1,7 cm larg., verde. Escapo ereto, 20-35 cm compr., verde; brácteas do escapo eretas, estreito-triangulares, acuminadas com ápice levemente recurvado ou retorcido, 2,5-5 cm compr., as inferiores maiores e as superiores igualando ou menores que os entrenós, verdes. Inflorescência em racemo heterotético duplo ou triplo, $20-45 \mathrm{~cm}$ secundiflora ou não, laxa, raque verde; brácteas primárias estreito-triangulares, acuminadas ou agudas e apiculadas, $2-4 \mathrm{~cm}$ compr., verdes; ramos 4-6, eretos a patentes, delicados, apresentando 1-2 brácteas estéreis na base e 1 no ápice; brácteas florais elípticas, eretas, agudas, $1,5-2 \times 0,8-1 \mathrm{~cm}$, mais curtas que as sépalas, inconspicuamente carenadas em direção ao ápice, verdes. Flores dísticas, pedicelos ca. $3 \mathrm{~mm}$ compr.; sépalas oblongas, obtusas, ca. $2 \times 6 \mathrm{~mm}$, verdes; pétalas eretas, alvas, estames exsertos.

Distribuição geográfica e habitat: Venezuela, Trinidad, Guiana, Suriname, Argentina, Parguai e Brasil: Piauí, Ceará, Paraíba, Pernambuco, Bahia, Espírito Santo, Rio de Janeiro, São Paulo, Paraná e Santa Catarina (Smith \& Downs 1977). Epífita na Floresta Pluvial Atlântica de baixo-montana e montana.

Material examinado: 18.VII.1993, fr., C. M. Vieira \& L. C. Gurken 312 (RB).

A espécie apresenta quatro variedades descritas, as quais se diferenciam basicamente pela presença de ramificações na inflorescência e pelo tamanho e consistência das brácteas florais. O táxon ocorrente em Macaé de Cima aproxima-se de $V$. procera var. tenuis L.B.Sm. Devido à ampla distribuição geográfica da espécie e à grande variação observada em relação à morfologia foliar, às brácteas florais e às corolas, é necessário um estudo mais abrangente para melhor circunscrição dos táxons.

27. Vriesea sparsiflora L.B.Sm., Contr. Gray Herb. 95: 48, fig. 1-2. 1931; Smith \& Downs, Fl. Neotrop. Monogr. 14(2): 1135, fig. 369 AB. 1977.

Planta florida até ca. $80 \mathrm{~cm}$ alt., epífita ou terrestre. Folhas suberetas a arqueadas, 
ca. $7 \mathrm{~cm}$ compr., formando roseta infundibuliforme; bainha elíptica, $8-9 \times 6 \mathrm{~cm}$, alvacenta; lâmina linear, acuminada, ca. $2 \mathrm{~cm}$ larg., verde. Escapo ereto, 22-26 cm compr., vermelho; brácteas inferiores do escapo ovadas, acuminadas, 3,5-4 cm compr., mais longas ou igualando os entrenós, verdes, as superiores ovadas, acuminadas, 2,5-3,5 cm compr., mais curtas que os entrenós. Inflorescência em racemo heterotético triplo, ca. $50 \times 30 \mathrm{~cm}$, secundiflora pelo menos na antese, laxa; brácteas primárias ovadas, agudas, 1-3 cm compr., mais curtas que os ramos; ramos 11-13, 20-30 cm compr., eretos a patentes, apresentando 1-5 brácteas estéreis na base; brácteas secundárias triangulares, agudas, ca. 1,5 cm compr.; ramulos com 3-4 brácteas basais semelhantes às brácteas secundárias, vermelhos; raque geniculada próximo ao ápice, apresentando até 4 flores e geralmente uma bráctea floral estéril no ápice; brácteas florais ovadas, agudas, apículo diminuto, até ca. $1 \times 0,6 \mathrm{~cm}$, menores que as sépalas, fracamente carenadas próximo ao ápice, secundas com as flores. Flores dísticas e patentes, pedicelos 2-3 mm compr.; sépalas oblongas, 1,3-1,5 cm compr., sem carena, amarelas com base verde; pétalas lineares, ca. $3,5 \mathrm{~cm}$ compr., eretas, alvas, apêndices lineares e obtusos, ca. 9 mm compr.; estames exsertos. Distribuição geográfica e habitat: São Paulo (Smith \& Downs 1977) e Rio de Janeiro. Floresta Pluvial Atlântica alto-montana. Ocorre em pequenas populações nas matas de altitude em Macaé de Cima e no Pico do Frade, Macaé. A população de São Paulo (Serra de Paranapiacaba) só é conhecida em coleção de herbário pela coleta do tipo.

Material examinado: 6.III.1991, fl., A. Costa et al. 352 (RB); 7.VII.1991, fr., A. Costa et al. 381 (RB); 18.VII.1993, fr., C. M. Vieira \& L. C. Gurken 312-A (RB); 18.IX.1986, fr., G. Martinelli et al. 11759 (RB).

Considerando a presença de pétalas lineares, estames exsertos e flores diurnas, a espécie deve ser incluída na seção Vriesea diferentemente do interpretado por Smith \& Downs (1977).
28. Vriesea triligulata Mez, in Mart., Eichler \& Urban, Fl. bras. 3(3): 541. 1894; Smith \& Downs, Fl. Neotrop. Monogr. 14(2):1108. 1977; Costa, Bromélia 2(4): 3-9. 1995.

Fig. 1 a

=Vriesea haematina L.B.Sm., Arq. Bot. Estado São Paulo II. 1: 177, fig. 123. 1943.

Planta florida até $80 \mathrm{~cm}$ alt., epífita. Folhas eretas ca. $44 \mathrm{~cm}$ compr., formando roseta infundibuliforme; bainha oblonga, 10$12 \times 5-7 \mathrm{~cm}$, atropurpúrea em ambas as faces ou apenas na face dorsal das folhas mais externas da roseta; lâmina linear, plicada, obtusa, acuminada, 4,5-5 cm larg., verde com linhas irregulares transversais mais escuras. Escapo ereto, 23-43 cm compr., vermelho; brácteas inferiores do escapo ovadas, agudas a obtusas, apiculadas, 3,8-5 cm compr., mais longas que os entrenós, eretas, verdes, as superiores ovadas a largo-ovadas, acuminadas, 3,5-4,5 cm compr., pouco mais curtas, igualando ou levemente mais longas que o entrenó, totalmente vermelhas ou vermelhas com ápice amarelo. Inflorescência em racemo heterotético duplo, ca. $44 \times 18-20 \mathrm{~cm}$, não secundiflora, laxa, raque vermelha; brácteas primárias ovadas, agudas, apiculadas ou brevemente acuminadas, ca. $3 \mathrm{~cm}$ compr., igualando a base da $2^{\text {a }}$ flor, vermelhas com nuances amarelas; ramos 5-8, 10-12 cm compr., levemente geniculados, raramente apresentando 1 ou 2 brácteas reduzidas na base, carenadas e estéreis; brácteas florais ovadas, obtusas, 2,5-3×1,5 cm, não carenadas ou levemente carenadas, amarelas. Flores dísticas, eretas a suberetas, pedicelo curto e robusto; sépalas elípticas, obtusas, ca. 2,5 cm compr., amarelas; pétalas lineares, ca. $3,5 \mathrm{~cm}$ compr., eretas, amarelas, apêndices obtusos com ápice levemente irregular, ca. $6 \mathrm{~mm}$ compr.; estames inclusos. Semente com apêndice apical até $3 \mathrm{~mm}$ compr.

Distribuição geográfica e habitat: Rio de Janeiro (Smith \& Downs 1977). Floresta Pluvial Atlântica montana, alto-montana e campos de altitude. Bastante freqüente na região de Macaé de Cima. Apresenta grande 
abundância nas matas de encosta da Serra dos Órgãos e estende sua distribuição até a Serra do Desengano, ao norte do estado.

Material examinado: 6.XII.1988,fl., A. Costa et al. 211-A (RB); 6.III.1991, fl., A. Costa et al. 351 (RB); 16.IV.1991, fl., A. Costa et al. 370 (RB); 16.IV.1991, fl., A. Costa et al. 376 (RB); 3.XII.1991, fr., A. Costa et al. 396 (RB); 4.II.1991, fl., A. Costa et al. 422 (RB); 17.VII.1993, fr., C. M. Vieira \& L. C. Gurken 294 (RB); 17.VII.1993, fr., C. M. Vieira \& L. C. Gurken 295 (RB); 9.IV.1989, fl., H. Q. Boudet Fernandes 2742 (MBML, RB).

Vriesea triligulata é bem definida tendo como principais características as folhas com bainhas atropurpúreas em ambas as faces e ápice obtuso. Além disso, a raque vermelha, as brácteas florais amarelas associadas à presença de estames inclusos fazem dela uma planta bastante característica. Durante algum tempo a espécie teve sua identidade confundida, entretanto, a análise de farto material, inclusive o tipo, permitiu o esclarecimento da questão (Costa 1995). Ocorre em densas touceiras, sendo raros os indivíduos solitários. Nos trechos de vegetação mais densa ocorre nas ramificações terminais das árvores emergentes e nas áreas mais abertas, a partir de $1,5 \mathrm{~m}$ do solo, caracterizando-se assim como uma espécie heliófila.

29. Vriesea vagans (L.B.Sm.) L.B.Sm., Phytologia 13: 118. 1966; Smith \& Downs, Fl. Neotrop. Monogr. 14(2): 1240-2, fig. 408 AB, 1977.

Planta florida 70-95 cm alt., estolonífera, epífita. Folhas eretas, 25-50 cm compr., formando roseta infundibuliforme; bainha oblonga a elíptica, $8-16 \times 3,5-5,5 \mathrm{~cm}$, alvacenta com grande mácula purpúrea no centro em ambas as faces e pequenas máculas esparsas entre a bainha e a lâmina; lâmina linear, acuminada, 2-2,5 cm larg., com linhas transversais irregulares verde mais escuro. Escapo ereto, 22-24 cm compr., verde; brácteas inferiores do escapo foliáceas, acuminadas, 11,5-28 cm compr., as medianas ovadas, agudas, 9,5-10,5 cm compr., verdes com manchas róseas, e as superiores estreito- ovadas, acuminadas, $6,5-8,5 \mathrm{~cm}$ compr., geralmente róseas com ápice verde, todas mais longas que os entrenós, com as metades superiores eretas a patentes. Inflorescência em racemo heterotético duplo ou triplo, 36$72 \mathrm{~cm}$, às vezes secundiflora, laxa; brácteas primárias inferiores semelhantes às brácteas superiores do escapo, até ca. $14 \mathrm{~cm}$ compr., geralmente igualando a metade do ramo, as superiores ovadas, acuminadas a agudas, apiculadas, 2,5-4,5 cm compr., de mais curtas a igualando o pedúnculo; ramos 10-13, eretos, os inferiores ca. $9 \mathrm{~cm}$ compr., com 2-3 brácteas estéreis e carenadas na base, os superiores 5-7 cm compr., geralmente com uma bráctea estéril na base; brácteas secundárias estreito-ovadas, acuminadas e incurvadas, 2,5-3 cm compr., carenadas; brácteas florais ovadas, agudas a acuminadas, 2,5-3,5 × 7-10 cm, carenadas em direção ao ápice, nervadas, de vermelhas a estramíneas. Flores dísticas, eretas, as do ápice dos ramos imbricadas na pré-antese, pedicelos ca. $4 \mathrm{~mm}$ compr.; sépalas estreito-elípticas, agudas, ca. 2,6 cm compr., verdes a amarelas; pétalas lineares, concrescidas por ca. $3 \mathrm{~mm}$, amarelas, eretas, apêndices obtusos, ca. $4 \mathrm{~mm}$ compr. no botão; estames exsertos.

Distribuição geográfica e habitat: Minas Gerais e Rio de Janeiro ao Rio Grande do Sul (Smith \& Downs 1977) e Espírito Santo. A espécie é bem distribuída na Floresta Pluvial Atlântica baixo-montana e montana até 1.000 m.s.m. Ocorre em áreas bem preservadas, mas é nas capoeiras e matas secas que aparece com maior frequiência. Na região de Macaé de Cima pode ser observada como epífita nas árvores na beira da estrada principal da reserva e em áreas degradadas. Até o momento não foi encontrada nas matas de encosta bem preservadas.

Material examinado: 2.II.1992, bot., A. Costa et al. 420 (RB); 8.III.1992, bot., A. Costa et al. 429 (RB).

A grande mancha purpúrea nas bainhas foliares e os estolões são características vegetativas marcantes na espécie. 


\section{Subfamília Bromelioideae}

30. Aechmea caesia E. Morren ex Baker, Handb. Bromel. 43. 1889; Smith \& Downs, Fl. Neotrop. Monogr. 14(3): 1886. 1979.

Fig. 2 q-r

Planta florida $45-60 \mathrm{~cm}$ alt., epífita. Folhas eretas, 20-45 cm compr., formando roseta tubulosa; bainha ovada, 10-25 × 6-9 cm, vinosa; lâmina linear, obtusa, 3-6 cm larg., verde, serrada, acúleos ca. $5 \mathrm{~mm}$ compr. Escapo ereto, 40-50 cm compr., purpúreo, lanuginoso a glabro; brácteas do escapo triangulares, acuminadas, serrilhadas, $3-3,5 \mathrm{~cm}$ compr., mais curtas que os entrenós, vermelhoescuras, papiráceas. Inflorescência em espiga dupla, piramidal, 6-10 $\times 4-5 \mathrm{~cm}$, densa; brácteas primárias triangulares, atenuadas, serrilhadas, 1,5-2,5 cm compr., róseas a avermelhadas; brácteas florais ovadas, obtusas e prolongadas em espinho ca. $4 \mathrm{~mm}$ compr., serrilhadas, ca. $1,5 \times 8 \mathrm{~mm}$, não carenadas, róseas a avermelhadas. Flores sésseis, ca. 1,5 cm compr.; sépalas ovadas, ligeiramente assimétricas, obtusas e cuculadas, ca. $3 \mathrm{~mm}$ compr., concrescidas por ca. $1 \mathrm{~mm}$, não carenadas; pétalas espatuladas, eretas, obtusas e cuculadas, ca. $1 \mathrm{~cm}$ compr., livres, azuis, apêndices fimbriados, ca. $3 \mathrm{~mm}$ compr.; estames inclusos; ovário não sulcado.

Distribuição geográfica e habitat: Rio de Janeiro (Smith \& Downs 1979). Espécie endêmica da Floresta Pluvial Atlântica montana, alto-montana e campos de altitude, como epífita ou terrestre entre 1.100 a 1.400 m.s.m. Material examinado: 16.IV.1991, fl., A. Costa et al. 367 (RB); 15.IX.1991, fr., E. L. Jacques et al. 236 (RB); 18.IX.1986, fl., G. Martinelli \& T. Wendt 11720 (RB); 26.VIII.1987, fl., M. Leitman et al. 258 (RB).

31. Aechmea coelestis (K. Koch) E. Morren, Fl. Serres 21: 5, pl. 2146. 1875; Smith \& Downs, Fl. Neotrop. Monogr. 14(3): 1872. 1979.

Fig. 3 o-p

Planta florida 50-60 cm alt., epífita. Folhas suberetas, $35-65 \mathrm{~cm}$ compr., formando roseta infundibuliforme; bainha ovada, 15-17 $\times$ 6-8 cm, alvacenta; lâmina linear, obtusa e acuminada, 4,5-6 cm larg., verde, margem laxamente serrada. Escapo 36-38 cm compr., ereto, vinoso, indumento lanuginoso, alvacento; brácteas do escapo triangulares, acuminadas, inteiras, 2-4 cm compr., mais longas que os entrenós, não encobrindo o escapo, verdes. Inflorescência em espiga dupla, piramidal, 9$19 \times 4-7 \mathrm{~cm}$, laxa, com indumento lanuginoso; brácteas primárias triangulares, atenuadas, inteiras, 2-3 cm compr., vermelhas a purpúreas; brácteas florais ovadas, atenuadas, inteiras, $1-$ $1,2 \times 0,3-0,5 \mathrm{~cm}$, não carenadas, vermelhas a púrpureas. Flores sésseis, $1-1,8 \mathrm{~cm}$ compr.; sépalas ovadas, ligeiramente assimétricas, ca. $4 \mathrm{~mm}$ compr., concrescidas por ca. $2 \mathrm{~mm}$, obtusas e prolongadas em espinho de ca. $5 \mathrm{~mm}$ compr., não carenadas, alvas a vinosas; pétalas espatuladas, obtusas e cuculadas, eretas, ca. $1 \mathrm{~cm}$ compr., livres, azuis, apêndices reduzidos; estames inclusos; ovário não sulcado.

Distribuição geográfica e habitat: Minas Gerais, Espírito Santo, Rio de Janeiro, São Paulo e Paraná (Smith \& Downs 1979). Epífita 1.000-1.400 m.s.m. na Floresta Pluvial Atlântica montana e alto-montana.

Material examinado: 1.II.1992,fl., A. Costa et al. 415 (RB); 25.V.1989, fl., G. Martinelli et al. 13429 (RB); 4.XII.1991, fr., T. Wendt \& A. Costa 216 (RB).

Aechmea coelestis inclui-se num complexo de espécies de difícil delimitação, como A. organensis Wawra, A. gracilis Lindm., A. caudata Lindm., A. candida E. Morren ex Baker e A. winkleri Reitz. Além da variedade típica, $A$. coelestis possui mais duas variedades descritas.

32. Aechmea ornata Baker, J. Bot. 17: 162. 1879; Smith \& Downs, Fl. Neotrop. Monogr. 14(3): 1919-20, fig. 657 A-F. 1979.

Fig. 2 k-1

Planta florida $75-90 \mathrm{~cm}$ alt., epífita. Folhas suberetas, 0,55-1,15 m compr., formando roseta infundibuliforme; bainha elíptica, $18-25 \times 7-11 \mathrm{~cm}$, castanha; lâmina linear, pungente, 4-6 cm larg., laxamente serrada. Escapo ereto ou ligeiramente curvo, 55-75 cm compr., vermelho; brácteas do escapo com bainhas elípticas e lâminas triangulares, pungentes, serrilhadas, $4-40 \mathrm{~cm}$ 
compr., mais longas que os entrenós, laxamente imbricadas, vermelhas, coriáceas. Inflorescência em espiga, estrobiliforme, $10-15 \mathrm{~cm}$; brácteas florais ovadas, obtusas, $1-1,5 \times 0,8-1,3 \mathrm{~cm}$, prolongadas em espinho de 1-2 cm compr., coriáceas, engrossadas para o ápice, inteiras, tricarenadas, côncavas e envolvendo o ovário, verdes a avermelhadas. Flores sésseis, 2,5$3,5 \mathrm{~cm}$ compr.; sépalas ovadas, ligeiramente assimétricas, obtusas, 0,3-1 cm compr., prolongadas em espinho de ca. $5 \mathrm{~mm}$, concrescidas por ca. $4 \mathrm{~mm}$, não carenadas, verdes; pétalas espatuladas, obtusas a ligeiramente agudas, eretas, ca. 2,5 cm compr., livres, liláses, apêndices fimbriados, ca. $3 \mathrm{~mm}$ compr.; estames exsertos, ovário não sulcado. Distribuição geográfica e habitat: São Paulo, Paraná e Santa Catarina (Smith \& Downs 1979) e Rio de Janeiro (Wendt 1997). No estado do Rio de Janeiro ocorre na Floresta Pluvial Atlântica como epífita ou terrestre, em outros estados ocorre também nas restingas. Material examinado: 17.XII.1992, fr., A. Costa et al. 444 (RB); 26.VI.1996, fl., C. M. Vieira \& L. C. Gurken 279 (RB); 18.IX.1986, fr., G. Martinelli \& T. Wendt 11763 (RB); 4.XII.1991, fr., T. Wendt \& A. Costa $217(\mathrm{RB})$.

Wendt (1997) trata A. ornata como um complexo de exemplares mal delimitados, que deve envolver mais de uma espécie, mas que, no presente estágio de conhecimento não é possível propor nomes mais apropriados. A ocorrência para o Rio de Janeiro era desconhecida até as coletas para Macaé de Cima.

33. Aechmea pineliana (Brongn. ex Planch.) Baker, J. Bot. 17: 232. 1879; Smith \& Downs, Fl. Neotrop. Monogr. 14(3): 1920-1, fig.658 AE. 1979.

Fig. 2 m-n

Planta florida 40-70 cm alt., epífita. Folhas eretas, 30-60 cm compr., formando roseta tubulosa; bainha ovada, $15-25 \times 7-9 \mathrm{~cm}$, internamente vinosa; lâmina linear, acuminada, 3,5-6 cm larg., serrilhada, verde até verdeavermelhada. Escapo ereto, $37-50 \mathrm{~cm}$, vermelho; brácteas do escapo estreito a largotriangulares, acuminadas, as superiores serrilhadas, 2-10 cm compr., mais longas que os entrenós, densamente imbricadas, vermelhas, papiráceas. Inflorescência em espiga, estrobiliforme, 4-7 cm; brácteas florais ovadas, obtusas e prolongadas em espinho de ca. $5 \mathrm{~mm}$, 0,7-1 ×0,5-0,7 cm, papiráceas, engrossadas no ápice, tricarenadas, inteiras, castanhas, côncavas, envolvendo o ovário. Flores sésseis, ca. 2 cm compr.; sépalas ovadas, ligeiramente assimétricas, ca. $7 \mathrm{~mm}$ compr., obtusas e prolongadas em espinho de ca. $2 \mathrm{~mm}$, livres, não carenadas, amarelas; pétalas espatuladas, arredondadas, 1-1,2 cm compr., livres, eretas, amarelas, apêndices fimbriados, ca. $2 \mathrm{~mm}$ compr.; estames inclusos; ovário não sulcado. Distribuição geográfica e habitat: Minas Gerais, Espírito Santo e Rio de Janeiro. Epífita ou terrestre na Floresta Pluvial Atlântica e nas restingas.

Material examinado: 16-18.XII.1992, fr., A. Costa et al. 442 (RB); 16-18.XII.1992, fr., A. Costa et al. 443 (RB); 18.IX.1986, fl., G. Martinelli \& T. Wendt 11721 (RB); 20.IV.1968, fr., P. I. S. Braga $865 \&$ R. Braga 7 (RB); 16.VII.1987, fr., S. V. Pessoa et al. 218 (RB); 25.VII.1996, fl., T. Fontoura et al. 191 (RB); 4.XII.1991, fr., T. Wendt \& A. Costa 218 (RB).

As populações de $A$. pineliana apresentam significativas variações morfológicas em diferentes localidades.

34. Ananas bracteatus (Lindl.) Schult. \& Schult. f. in Roem. \& Schult., Syst. veg. 7(2): 1286. 1830; Smith \& Downs, Fl. Neotrop. Monogr. 14(3): 2059-60, fig. 729 A-B. 1979.

Planta terrestre. Folhas arqueadas, ca. 1,4 m compr., formando roseta ampla; bainha linear pouco diferenciada da lâmina, minutamente serrilhada, ca. $12 \times 5 \mathrm{~cm}$, avermelhada; lâmina linear, longo-atenuada, laxamente serrada, 3$4 \mathrm{~cm}$ larg., verde, as internas da roseta até a metade vermelhas. Escapo ereto, verde-vinoso; brácteas do escapo lineares, longo-atenuadas, serrilhadas, 9-27 cm compr., mais longas que os entrenós, vermelhas com ápice esverdeado. Inflorescência estrobiliforme, encimada por coroa de brácteas estéreis, ca. $10 \mathrm{~cm}$; brácteas florais triangulares, longo-atenuadas, 3-4 × 1$1,5 \mathrm{~cm}$, carenadas na base, serrilhadas, vermelhas, côncavas, engrossadas na base. Flores com 


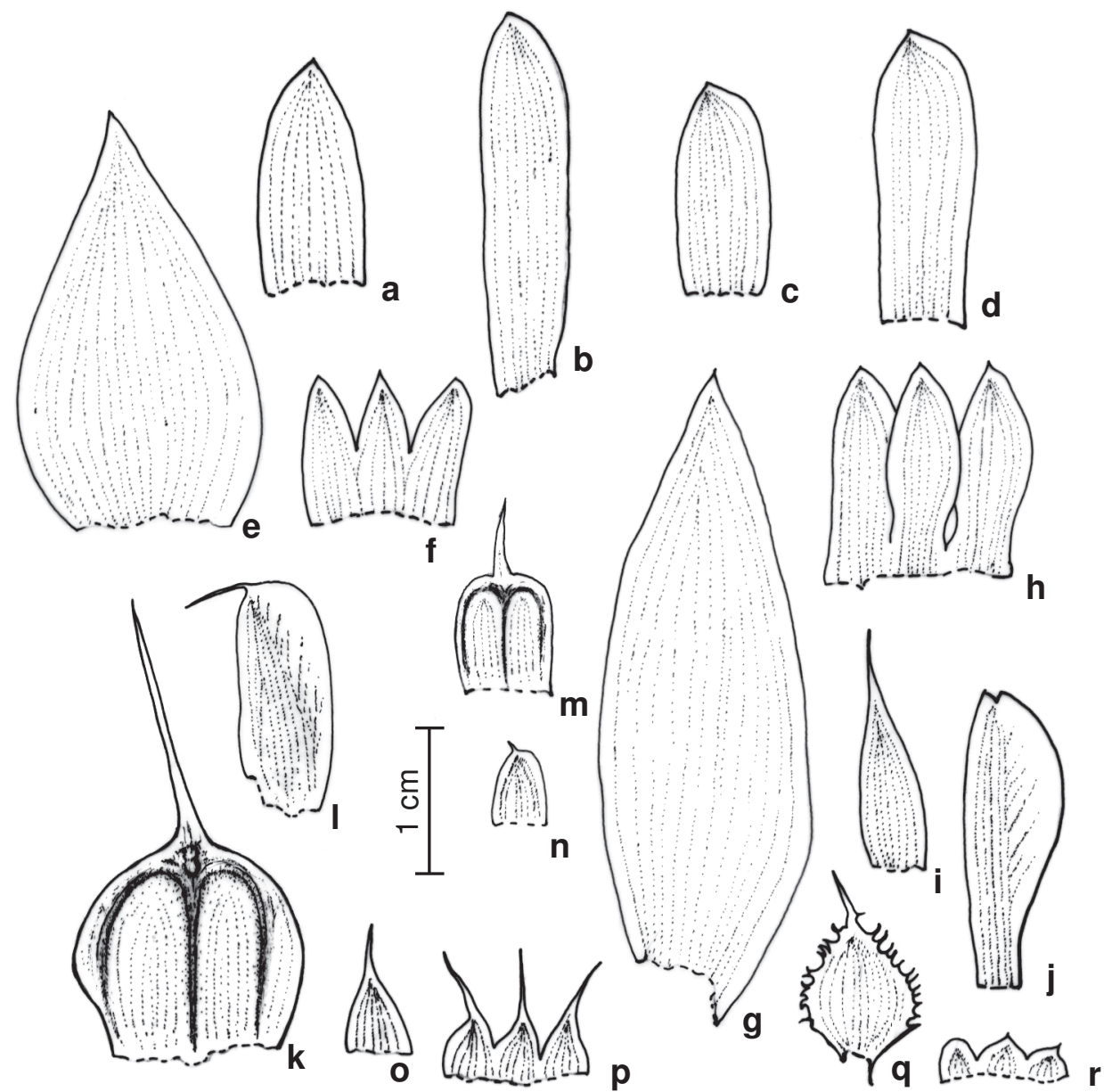

Figura 2 - Billbergia sanderiana - a. bráctea floral; b. sépala (Wendt 238). B. pyramidalis - c. sépala (Wendt 237). B. amoena - d. sépala (Martinelli 11825). Quesnelia lateralis - e. bráctea floral; f. sépalas (Costa 406). Q. strobilispica g. bráctea floral; h. sépalas (Vieira 419). Q. liboniana -i. bráctea floral; j. sépala (Vieira 106). Aechmea ornata - k. bráctea floral; 1. sépala (Vieira 279). A. pineliana - m. bráctea floral; n. sépala (Pessoa 218). A. coelestis - o. bráctea floral; p. sépalas (Costa 415). A. caesia - q. bráctea floral; r. sépalas (Costa 367).

ovários coalescentes; sépalas ovadas, ligeiramente assimétricas, obtusas e acuminadas, ca. 1,2 cm compr., concrescidas ca. $3 \mathrm{~mm}$, carenadas, carnosas, vermelhas; pétalas espatuladas, agudas, ca. $2,5 \mathrm{~cm}$ compr., livres, roxas, apêndices não observados; estames inclusos.

Distribuição geográfica e habitat: Paraguai, Argentina e Brasil: Espírito Santo, Rio de Janeiro, São Paulo, Paraná, Santa Catarina e Rio Grande do Sul (Smith \& Downs 1979) e Minas Gerais (Versieux \& Wendt 2006). No Brasil ocorre na Floresta Pluvial Atlântica e na restinga.
Material examinado: 27.XI.1986, fl., G. Martinelli et al. 11974 (RB).

A espécie aparece identificada como $A$. annanassoides (Baker) L.B.Sm. em GuedeBruni \& Lima (1994).

35. Billbergia amoena (Lodd.) Lindl., Bot. Reg. 13: sub. pl. 1068. 1827; Smith \& Downs, Fl. Neotrop. Monogr. 14(3): 1980-3, fig. 687 IK. 1979.

Fig. $2 \mathrm{~d}$

Planta florida ca. $50 \mathrm{~cm}$ alt., estolonífera, epífita ou terrestre. Folhas seberetas, 22-45 $\mathrm{cm}$ compr., as mais externas mais curtas, formando roseta infundibuliforme; bainha 
elíptica, 5-18 ×3-5 cm; lâmina linear, aguda a obtusa e acuminada, serrilhada, 2-5 cm larg., verde ou vinosa. Escapo ereto, verde; brácteas do escapo oblongas, acuminadas, inteiras, membránaceas, 5,5-8,5 cm compr., maiores que os entrenós, vermelhas. Inflorescência em espiga ou em espiga dupla, laxa; brácteas florais escamiformes. Flores sésseis, ca. $6 \mathrm{~cm}$ compr.; sépalas lineares, ligeiramente assimétricas, obtusas e apiculadas, ca. $2 \mathrm{~cm}$ compr., livres, não carenadas, verdes com ápice azul; pétalas lineares, obtusas, ca. 4,5 $\mathrm{cm}$ compr., recurvadas, apresentando 2 espessamentos longitudinais até $1 / 3$ do seu compr., livres, verde-amareladas com ápice azul, apêndices fimbriados; estames exsertos; ovário sulcado.

Distribuição geográfica e habitat: Goiás, Bahia, Minas Gerais, Espírito Santo, Rio de Janeiro, São Paulo, Paraná e Santa Catarina (Smith \& Downs 1979). Floresta Pluvial Atlântica montana, nas matas de restinga e nos campos rupestres, como epífita, terrestre e saxícola, do nível do mar até 1.300 m.s.m Material examinado: 25.X.1986, fl., G. Martinelli \& M. Leitman 11825 (RB).

36. Billbergia pyramidalis (Sims) Lindl., Bot. Reg. 13: sub. pl. 1068. 1827; Smith \& Downs, Fl. Neotrop. Monogr. 14(3): 2007-10, fig. 701 A-D. 1979.

Fig. $2 \mathrm{c}$

Planta florida $30-50 \mathrm{~cm}$ alt., epífita ou terrestre. Folhas suberetas, 40-90 cm compr., as mais externas menores, formando roseta infundibuliforme; bainha ovada a elíptica, 10 $24 \times 3,5-8 \mathrm{~cm}$, verde-clara; lâmina linear, acuminada, serrilhada, $3-4,5 \mathrm{~cm}$ larg., verde com indumento argênteo denso, formando ou não faixas transversais na face dorsal. Escapo ereto, 23-38 cm compr., róseo a alvo, com indumento alvo, denso; brácteas do escapo elípticas, acuminadas, inteiras ou serrilhadas, congestas abaixo da inflorescência, $5,5-8,5 \mathrm{~cm}$ compr., maiores que os entrenós, de cor rosa forte, indumento alvo, denso. Inflorescência em espiga, globosa, 10-12 cm compr., densa; brácteas florais escamiformes ou ausentes.
Flores sésseis, ca. 6,5 cm compr.; sépalas lineares, ligeiramente assimétricas, obtusas, ca. $1,5 \mathrm{~cm}$ compr., livres, não carenadas, róseas com indumento alvo; pétalas lineares, obtusas, ca. $5 \mathrm{~cm}$ compr., recurvadas, apresentando 2 calosidades longitudinais até $1 / 2$ do seu comprimento, livres, róseas (ou raramente amarelas) com ápice lilás a roxo, apêndices fimbriados; estames exsertos; ovário sulcado. Distribuição geográfica e habitat: A espécie é distribuída pelos estados da Bahia, Minas Gerais, Espírito Santo, Rio de Janeiro e São Paulo nas matas de restinga e nas florestas de encosta (Moura et al. 2007). Sua ocorrência em Cuba, Venezuela e no Pará (Smith \& Downs 1979) necessita confirmação através de análise das coleções de herbário. Ocorre na Floresta Pluvial Atlântica montana e nas matas de restinga.

Material examinado: 2.XII.1991, fl., A. Costa et al. 390 (RB); 3.XII.1991, fl., A. Costa et al. 399 (RB); 4.XII.1991, fl., A. Costa et al. 404 (RB); 5.XII.1991, fl., A. Costa et al. 410 (RB); 14.VIII.1989, fl., C. $M$ Vieira 72 (RB); 28.VIII.1994, fl., C. M. Vieira \& L. C. Gurken 632 (RB); 27.XI.1986, fl., G. Martinelli et al. 11950 (RB); II.1992, fl., T. Wendt et al. 237 (RB).

37. Billbergia sanderiana E. Morren, Belgique Hort. 34: 17, pls. 1, 2. 1884; Smith \& Downs, Fl. Neotrop. Monogr., 14(3): 1996, fig. 694 A-G 1979.

Fig. 2 a

Planta florida ca. $45 \mathrm{~cm}$ alt., epífita. Folhas suberetas, 28-36 cm compr., formando roseta infundibuliforme; bainha elíptica, 13-17× 6-9 cm, castanha com manchas vinosas na face ventral; lâmina linear, obtusa a retusa e apiculada, serreada, acúleos nigrescentes, ca. $6 \mathrm{~cm}$ larg., verde. Escapo curvo, ca. $45 \mathrm{~cm}$ compr., vinoso; brácteas do escapo ovadas, acuminadas, serreadas ou não próximo ao ápice, ca. $7 \mathrm{~cm}$ compr., igualando os entrenós, róseas com indumento alvo, membranáceas. Inflorescência em espiga dupla, ca. $25 \mathrm{~cm}$ compr., pendente, laxa; brácteas primárias semelhantes às do escapo com indumento apenas próximo ao ápice; brácteas florais ovadas, agudas e apiculadas, levemente incurvadas, $1,2-2,3 \times 0,8 \mathrm{~cm}$, róseas, 
membranáceas, com indumento no ápice. Flores sésseis, 6-7 cm compr.; sépalas lineares, agudas e minutamente apiculadas, ca. 2,6 cm compr., livres, não carenadas, róseas com ápice azul; pétalas lineares, ca. 5,2 cm compr., obtusas, recurvadas, apresentando 2 calosidades longitudinais até $1 / 2$ do seu comprimento, livres, verde-amareladas, apêndices fimbriados, ca. 2 mm compr.; estames exsertos; ovário sulcado. Distribuição geográfica e habitat: Minas Gerais, Espírito Santo e Rio de Janeiro (Smith \& Downs 1979). Floresta Pluvial Atlântica e nas matas de galeria dos campos rupestres, como epífita.

Material examinado: 1.XII.1992, fl., T. Wendt et al. 238 (RB).

38. Canistropsis microps (E. Morren ex Mez) Leme, Canistropsis, Bromélias da Mata Atlântica, 35. 1998. Fig. 3 j 三Nidularium microps E. Morren ex Mez in Mart., Eichler \& Urban, Fl. bras. 3(3): 218. 1892; Smith \& Downs, Fl. Neotrop. Monogr. 14(3): 1607-9, fig. 523 F-G. 1979.

Planta estolonífera, epífita. Folhas suberetas, 22-37 cm compr., formando roseta infundibuliforme; bainha obovada, $7-8 \times 3,5 \mathrm{~cm}$, verde com indumento castanho; lâmina linearoblanceolada, acuminada, serrilhada, 2-2,5 cm larg., verde com faixa central longitudinal mais clara. Escapo ereto, 7-7,5 cm compr.; brácteas inferiores do escapo foliáceas, ovadas, longoatenuadas, inconspicuamente serrilhadas, verdes, as superiores ca. 3,5 cm compr., mais longas que os entrenós, vermelhas. Inflorescência em espiga dupla, capituliforme, embutida na roseta, ca. 3,5 × 3-6 cm, densa; brácteas primárias ovadas, acuminadas, serrilhadas, $4-4,5 \mathrm{~cm}$ compr., vermelhas; brácteas florais ovadas, agudas e apiculadas, ca. 1,3×0,6-0,7 cm, inteiras, não carenadas. Flores sésseis, ca. 2,5 cm compr.; sépalas ovadas, ligeiramente assimétricas, agudas e acuminadas, ca. 1,3 cm compr., concrescidas por ca. $3 \mathrm{~mm}$, não carenadas, vermelhas, tornando-se azuladas na frutificação; pétalas lineares, ca. 1,7 cm compr., ápice patente e acuminado, concrescidas por ca. $1 \mathrm{~cm}$, alvas, sem apêndices; estames inclusos.
Distribuição geográfica e habitat: Rio de Janeiro, São Paulo e Santa Catarina (Leme 1998). Floresta Pluvial Atlântica montana e alto-montana. Material examinado: 25.X.1986, bot., G. Martinelli et al. 11829 (RB); 2.XII.1991, fl., T. Wendt \& A. Costa 209 (RB).

39. Edmundoa lindenii (Regel) Leme, Canistrum, Bromélias da MataAtlântica, 46. 1997. 三 Canistrum lindenii (Regel) Mez in Mart., Eichler \& Urban, Fl. bras. 3(3): 256. 1891; Smith \& Downs, Fl. Neotrop. Monogr. 14(3): 1722-5, fig. 576 E-J. 1979.

Planta florida ca. $30 \mathrm{~cm}$ alt., epífita. Folhas suberetas, 58-93 cm compr., formando roseta infundibuliforme; bainha largo elíptica, 12-14 $\times$ 7,5-10,5 cm, alva; lâmina linear, acuminada, irregularmente serrilhada, ca. $7 \mathrm{~cm}$ larg., verde com faixa longitudinal central mais clara. Escapo ereto, ca. 20 cm compr., evidente; brácteas do escapo ovadas a triangulares, acuminadas, irregularmente serrilhadas, 5-6 cm compr., mais longas que os entrenós, verde-pálidas. Inflorescência em racemo heterotético duplo, umbeliforme, 10-12× $14 \mathrm{~cm}$, sobressaindo da roseta, envolvida por invólucro de brácteas, densa; brácteas florais ovadas, acuminadas, ca. $3 \times 0,9$ cm, não carenadas, cobertas por lanugem castanha. Flores ca. $3,5 \mathrm{~cm}$ compr., curto-pediceladas; sépalas largo-elípticas, assimétricas, agudas, ca. 1,5 cm compr., livres, não carenadas, alvas; pétalas e frutos não observados. Distribuição geográfica e habitat: Espírito Santo, Minas Gerais, Rio de Janeiro, São Paulo, Paraná, Santa Catarina e Rio Grande do Sul (Leme 1997). Floresta Pluvial Atlântica.

Material examinado: 2.XII.1991, fl., T. Wendt et al. 207 (RB).

40. Neoregelia carolinae (Beer) L.B.Sm., Contr. Gray Herb. 124: 9. 1939; Smith \& Downs, Fl. Neotrop. Monogr., 14(3): 1552-3, fig. 500 G-K.1979.

Fig. 3 b

Planta epífita. Folhas suberetas, 54-60 cm compr., formando roseta infundibuliforme; bainha elíptica, $11-12 \times 5-5,5 \mathrm{~cm}$, verde a alva; lâmina linear, acuminada, 2,5-2,7 cm larg., serrilhada, verde, as internas com o terço mediano róseo na floração. Escapo ereto, ca. 6 cm compr., não 
evidente; brácteas inferiores do escapo largotriangulares, atenuadas, as superiores largooblongas, arredondadas e acuminadas, nítida a inconspicuamente serrilhadas, 4,5-5 cm compr., maiores que os entrenós. Inflorescência em racemo, umbeliforme, embutida na roseta, ca. $4 \times 3 \mathrm{~cm}$, densa; brácteas florais lineares, arredondadas, retusas e minutamente apiculadas, inteiras, ca. 4,5 $\times 0,8 \mathrm{~cm}$, não carenadas. Flores ca. 3,5 cm compr., curto-pediceladas; sépalas obovadas, ligeiramente assimétricas, agudas, minutamente apiculadas e incurvadas, $2 \mathrm{~cm}$ compr., concrescidas por ca. $5 \mathrm{~mm}$, não carenadas, verdes; pétalas lineares, agudas, ca. $2 \mathrm{~cm}$ compr., concrescidas por mais da metade, liláses, sem apêndices, ápice patente na antese; estames inclusos.

Distribuição geográfica e habitat: Smith \& Downs (1979) indicam sua ocorrência para o Rio de Janeiro e Bahia, no entanto este último estado precisa ser averiguado. Ocorre também no Espírito Santo. Epífita ou terrestre na Floresta Pluvial Atlântica montana entre 1.000 e 1.380 m.s.m.

Material examinado: 3.XII.1991, fl., A. Costa et al. 403 (RB).

41. Neoregelia fluminensis L.B.Sm., Smithson. Misc. Collect. 126: 27, 150, fig. 58. 1955; Smith \& Downs, Fl. Neotrop. Monogr. 14(3): 1565, fig. 504 A-C, 512 I. $1979 . \quad$ Fig. 3 d

Planta epífita, estolonífera. Folhas 33$52 \mathrm{~cm}$ compr.; bainha ovada, $6-10 \times 3-5,5 \mathrm{~cm}$, vinosa; lâmina linear, obtusa e apiculada, 2 $3 \mathrm{~cm}$ larg., serrilhada, verde. Escapo ca. $5 \mathrm{~cm}$ compr., não evidente, alvo; brácteas do escapo ovadas, acuminadas, inteiras, ca. $3 \mathrm{~cm}$ compr., mais longas que os entrenós, alvas. Inflorescência em racemo, umbeliforme, embutida na roseta, ca. $4 \times 4 \mathrm{~cm}$, densa; brácteas florais elípticas, agudas, minutamente apiculadas, inteiras, ca. 2,7 ×0,7 cm, não carenadas. Flores com pedicelos ca. 1,7 cm compr;; sépalas ovadas, ligeiramente assimétricas, agudas, ca. 1,5 cm compr., concrescidas por ca. $2 \mathrm{~mm}$, levemente carenadas, vinosas no fruto; pétalas não observadas.
Distribuição geográfica e habitat: Rio de Janeiro (Smith \& Downs 1979). Floresta Pluvial Atlântica montana.

Material examinado: 25.X.1986, fr., G. Martinelli \& M. Leitman 11835 (RB).

Além do registro para Macaé de Cima, é conhecida apenas a coleta do tipo em Teresópolis (Foster 982, GH, holótipo n.v.).

42. Neoregelia leucophoea (Baker) L.B.Sm., Contr. Gray Herb. 124: 9. 1939; Smith \& Downs, Fl. Neotrop. Monogr. 14(3): 1578. 1979; Leme, Canistropsis, Bromélias da Mata Atlântica, 64. $1998 . \quad$ Fig. 3 a = Wittrockia leucophoea (Baker) Leme, J. Bromeliad Soc. 41(4): 147-154, fig. 1-5. 1991.

Planta florida ca. $40 \mathrm{~cm}$ alt., epífita ou terrestre. Folhas eretas $42-45 \mathrm{~cm}$ compr., formando roseta infundibuliforme; bainha oblonga, ca. $18 \times 9 \mathrm{~cm}$, castanhas com manchas vinosas, face ventral com base alva, indumento castanho denso; lâmina linear, obtusa e apiculada, irregularmente serreada, acúleos verdes, ca. $5 \mathrm{~cm}$ larg., verde com máculas esparsas vinosas pouco evidentes. Escapo ereto, ca. $8 \mathrm{~cm}$ compr., embutido na roseta, glabro; brácteas do escapo largo-ovadas, acuminadas, as inferiores serrilhadas, 3,5-4 cm compr., mais longas que os entrenós, alvas com indumento castanho denso, e as superiores com ápice vinoso, inteiras, membranáceas, com indumento alvo esparso. Inflorescência em racemo, umbeliforme, embutida no fundo da roseta, ca. $5,5 \times 4,5 \mathrm{~cm}$; brácteas florais lineares, obtusas e acuminadas, inteiras, ca. $5 \times 0,8 \mathrm{~cm}$, não carenadas, membranáceas, alvas com ápice vinoso. Flores ca. $7 \mathrm{~cm}$ compr., pedicelos ca. 1,6 cm compr.; sépalas lineares, fortemente assimétricas, acuminadas, ca. 2,5 cm compr., concrescidas por ca. $2 \mathrm{~mm}$, não carenadas, hialinas com parte apical central vinosa; pétalas obovadas, agudas, com os ápices sobrepostos na antese, ca. $3,8 \mathrm{~cm}$ compr., concrescidas por ca. $2,8 \mathrm{~cm}$, vinosas com ápice alvo, apêndices recortados; estames inclusos.

Distribuição geográfica e habitat: Rio de Janeiro (Leme 1998). Floresta Pluvial Atlântica montana. 

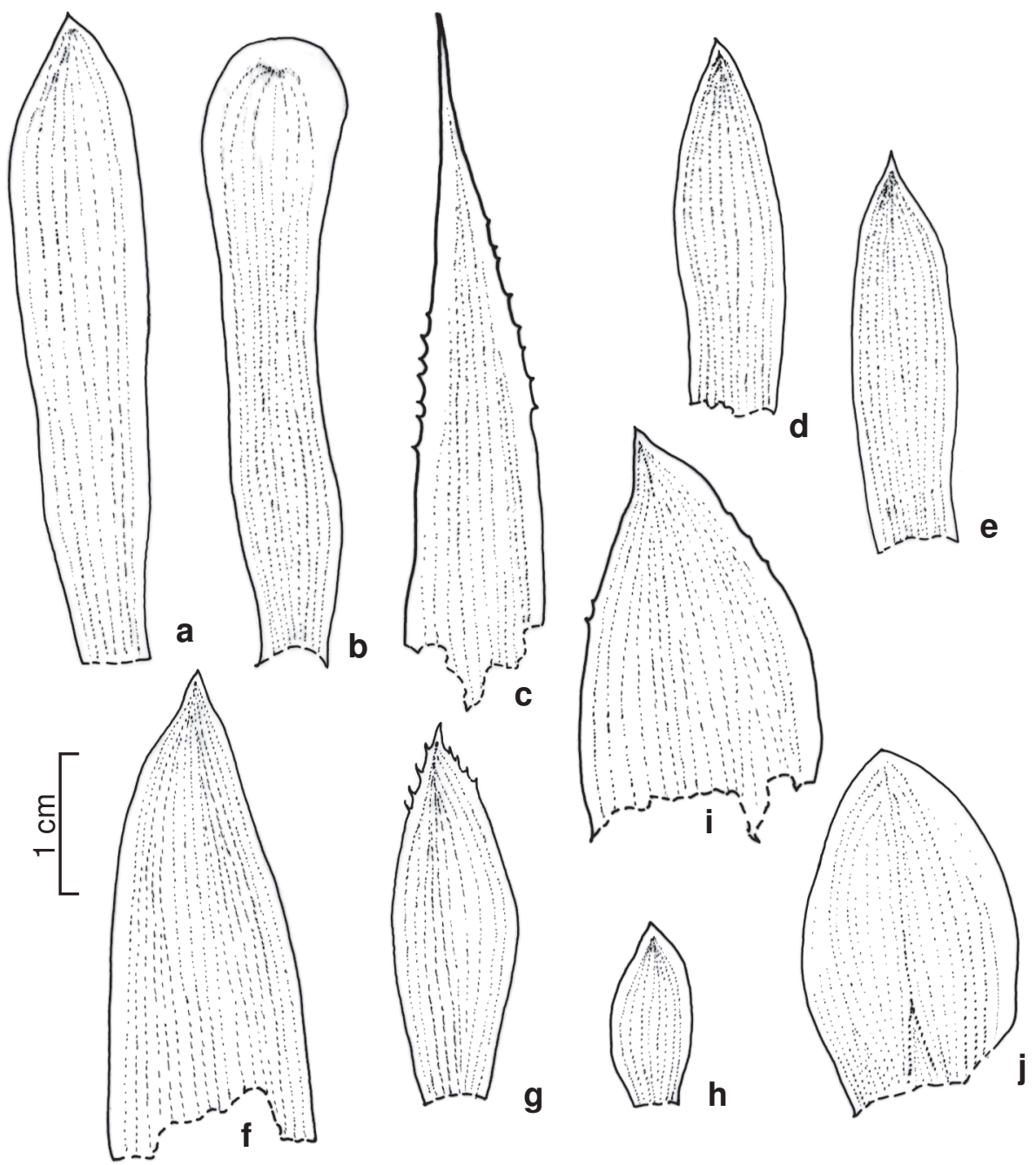

Figura 3 - Brácteas florais: a. Neoregelia leucophoea (Costa 508); b. N. carolinae (Costa 403); c. N. lymaniana (Costa 413); d. N. fluminensis (Martinelli 11835); e. N. tenebrosa (Leme 4107); f. Nidularium procerum (Costa 408); g. N. scheremetiewii (Costa 363); h. N. longiflorum (Costa 402); i. N. innocentii (Costa 405); j. Canistropsis microps (Wendt 209).

Material examinado: II.1995, fl., A. Costa et al. 508 (RB).

43. Neoregelia lymaniana $\mathrm{R}$. Braga \& Sucre, Revta. Bras. Biol. 34(4): 491, fig. 1-3. 1974; Smith \& Downs, Fl. Neotrop. Monogr. 14(3): 1547. 1979.

Fig. $3 \mathrm{c}$

Planta epífita. Folhas suberetas, $40-45$ cm compr., formando roseta infundibuliforme; bainha largo-elíptica, $11-12 \times 7,5-8 \mathrm{~cm}$, alvacenta, indumento esparso e castanho; lâmina linear, acuminada, 3,3-3,8 cm larg., verde, serrilhada com acúleos castanhos, as internas com o terço mediano rosa na floração.
Escapo ereto, ca. 5 cm compr., não evidente, alvacento; brácteas do escapo triangulares, atenuadas, serrilhadas, inferiores ca. $2,8 \mathrm{~cm}$ compr., alvas, e superiores ca. 3,2-5,5 cm compr., róseas. Inflorescência racemo heterotético duplo, umbeliforme, embutida na roseta, ca. 6 $\times 9 \mathrm{~cm}$, densa; brácteas primárias semelhantes às brácteas superiores do escapo; brácteas florais estreito-triangulares, longo-atenuadas, serrilhadas, ca. $5 \times 1,2 \mathrm{~cm}$, levemente carenadas, róseas. Flores ca. $3 \mathrm{~cm}$, pedicelos ca. $7 \mathrm{~mm}$ compr.; sépalas ovadas, ligeiramente assimétricas, caudadas, ca. 2,2 cm compr., concrescidas por ca. $2 \mathrm{~mm}$, carenadas, alvas com ápice róseo; 
pétalas lineares, agudas, ca. 2,4 cm compr., concrescidas por ca. $1,5 \mathrm{~cm}$, sem apêndices, alvas com ápice azul, ápice patente na antese; estames inclusos.

Distribuição geográfica e habitat: Rio de Janeiro (Smith \& Downs 1979) e Minas Gerais. Endêmica da Floresta Pluvial Atlântica montana, como epífita.

Material examinado: 5.XII.1991, fl., A. Costa et al. 413 (RB).

Material adicional examinado: Petrópolis, estrada Itaipava-Teresópolis, XI.1968, fl., R. Braga 32 (RB, holótipo).

Rara na área. Além do material aqui estudado só é conhecida a coleta do tipo.

44. Neoregelia tenebrosa Leme, Canistropsis, Bromélias da Mata Atlântica, p. 70. 1998.

Fig. $3 \mathrm{e}$

Planta epífita ou terrestre. Folhas suberetas, 25-66 cm compr., formando roseta infundibuliforme; bainha ovada, $17-19 \times 5-6 \mathrm{~cm}$; lâmina linear, obtusa e cuspidada, $3,5-5,5 \mathrm{~cm}$ larg., serrilhada, verde com mancha roxa no ápice. Escapo ereto, ca. $8 \mathrm{~cm}$ compr., não evidente; brácteas do escapo ovadas, obtusas e cuspidadas, serrilhadas, ca. $3 \mathrm{~cm}$ compr., mais longas que os entrenós. Inflorescência em racemo, umbeliforme, embutida na roseta; brácteas florais lineares, agudas, inteiras, ca. $2,3 \times 0,3 \mathrm{~cm}$, não carenadas. Flores ca. $10 \mathrm{~cm}$ compr., pedicelos ca. $3 \mathrm{~cm}$ compr.; sépalas lineares, simétricas, agudas, ca. 4,5 cm compr., concrescidas por ca. $1 \mathrm{~cm}$, não carenadas; pétalas lineares, agudas, ca. $10 \mathrm{~cm}$ compr., concrescidas por ca. $4 \mathrm{~cm}$, sem apêndices, alvas com ápice e margens purpúreos, ápice patente na antese; estames exsertos.

Distribuição geográfica e habitat: Rio de Janeiro. A espécie é restrita à Floresta Pluvial Atlântica alto-montana e campos de altitude dos municípios de Nova Friburgo e Teresópolis (Leme 1998).

Material examinado: 4.X.1997, fl., Leme et al. 4107 (HB, parátipo).

A espécie aparece identificada como Wittrockia bragarum E. Pereira \& L.B.Sm. em Guedes-Bruni \& Lima (1994).
45. Nidularium innocentii Lem., Ill. Hort. 2: 13. 1855; Smith \& Downs, Fl. Neotrop. Monogr. 14(3): 1613-5, fig. 526 A-D. 1979; Leme, Nidularium, Bromélias da Mata Atlântica, 144. 2000.

Fig. $3 \mathrm{i}$

Planta epífita, estolonífera. Folhas suberetas, 36-50 cm compr.; bainha ovada, 9$13 \times 5-7 \mathrm{~cm}$, base alva, indumento denso, castanho; lâmina linear-oblanceolada, acuminada, densamente serrilhada, $2,5-4 \mathrm{~cm}$ larg., face ventral verde com faixa longitudinal mais clara e face dorsal vinosa a verde. Escapo ereto, 6-8 cm compr.; brácteas do escapo elípticas, acuminadas, serrilhadas, $4-5$ cm compr., mais longas que os entrenós. Inflorescência espiga dupla, capituliforme, embutida na roseta, ca. $8 \times 8 \mathrm{~cm}$, densa; brácteas primárias com bainhas ovadas e lâminas triangulares, acuminadas, serrilhadas, 4,5-9 cm compr., medianas mais longas, vermelhas; brácteas florais elípticas, obtusas, inteiras, ca. $2,5 \times 1,5 \mathrm{~cm}$, carenadas na base, alvas. Flores ca. $6 \mathrm{~cm}$ compr., sésseis; sépalas ovadas, ligeiramente assimétricas, obtusas e minutamente apiculadas e incurvadas, ca. 2,7 $\mathrm{cm}$ compr., concrescidas por ca. $1 \mathrm{~cm}$, levemente tricarenadas em direção ao ápice, vermelhas a alvas; pétalas lineares, eretas, obtusas e cuculadas, sem calosidades basais, ca. 4,8 cm compr., concrescidas por ca. 3,5 $\mathrm{cm}$, verdes com ápice alvo; estames inclusos. Distribuição geográfica e habitat: Bahia, Espírito Santo, Rio de Janeiro, São Paulo, Paraná, Santa Catarina e Rio Grande do Sul (Leme 2000). Floresta Pluvial Atlântica montana e alto-montana. Material examinado: 3.XII.1991, fl., A. Costa et al. 400 (RB); 4.XII.1991, fl., A. Costa et al. 405 (RB); 12.IX.1989, fl., A. F. Vaz 644 (RB); 18.IX.1986, fl., G. Martinelli et al. 11722 (RB); 5.X.1987, fl., G. Martinelli et al. 12249 (RB).

46. Nidularium longiflorum Ule, Ber. Deutsch. Bot. Ges. 14: 408. 1896; Smith \& Downs, Fl. Neotrop. Monogr. 14(3): 1619. 1979; Leme, Nidularium, Bromélias da Mata Atlântica, 159. 2000.

Fig. $3 \mathrm{~h}$

Planta florida ca. $35 \mathrm{~cm}$ alt., estolonífera, epífita. Folhas suberetas, $20-45 \mathrm{~cm}$ compr., 
formando roseta infundibuliforme; bainha elíptica, ca. $10 \times 4-5 \mathrm{~cm}$; lâmina linear-oblanceolada, acuminada, serrilhada, 2,5-3 cm larg., verde. Escapo ereto, ca. $9 \mathrm{~cm}$ compr., igualando a altura das bainhas; brácteas do escapo triangulares, acuminadas, serrilhadas, ca. $7 \times 1,5 \mathrm{~cm}$, mais longas que os entrenós. Inflorescência em espiga dupla, capituliforme, não embutida na roseta, 8-9×4-5 cm; brácteas primárias, largo-ovadas, acuminadas, irregularmente serrilhadas, 5-9,5 $\times 3-4 \mathrm{~cm}$, vermelhas com base verde, as externas estéreis e as medianas mais longas; brácteas florais triangulares, agudas, irregularmente serrilhadas, ca. $3 \times 1,7 \mathrm{~cm}$, levemente carenadas no ápice. Flores sésseis, ca. 4 cm compr.; sépalas ovadas, levemente assimétricas, obtusas e mucronadas, ca. 2,5 cm compr., concrescidas por 7-8 mm, não carenadas, verdes; pétalas lineares, eretas, obtusas e cuculadas, ca. $3 \mathrm{~cm}$ compr., com calosidades basais evidentes, concrescidas, verdes com ápice alvo; estames inclusos.

Distribuição geográfica e habitat: Espírito Santo, Rio de Janeiro e São Paulo (Leme 2000), e Minas Gerais. Endêmica daFloresta Pluvial Atlântica montana e alto-montana até ca. 1500 m.s.m. Material examinado: 3.XII.1991, fl., A. Costa \& T. Wendt 402 (RB).

A espécie $N$. pauciflorum Ule citada por Fontoura et al. (1991) é um sinônimo de $N$. longiflorum (Leme 2000).

47. Nidularium procerum Lindm., Sv. Vet.akad. Handl. 24(8): 16. 1891; Smith \& Downs, Fl. Neotrop. Monogr. 14(3): 1624-6, fig. 530 D-F. 1979; Leme, Nidularium, Bromélias da Mata Atlântica, 100. 2000.

Fig. $3 \mathrm{f}$

Planta florida ca. $40 \mathrm{~cm}$ alt., epífita ou terrestre. Folhas suberetas, ca. $1 \mathrm{~m}$ compr.; bainha elíptica, $11-13 \times 4,5-5 \mathrm{~cm}$, alvacenta, indumento denso, castanho; lâmina linear, acuminada, densamente serrilhada, ca. $2,5 \mathrm{~cm}$ larg., verde com estrias irregulares transversais mais claras. Escapo ereto, ca. 30 cm compr.; brácteas do escapo foliáceas, 22-40 cm compr., mais longas que os entrenós, vinosas na base e verdes no ápice. Inflorescência em espiga dupla, capituliforme, não embutida na roseta, ca. $12 \times 15 \mathrm{~cm}$, densa; brácteas primárias com bainhas ovadas e lâminas triangulares, agudas e pungentes, densamente serrilhadas, 9-13 cm compr., vermelhas com ápice verde; brácteas florais triangulares, agudas, ca. 3,5× $1,5 \mathrm{~cm}$, levemente carenadas, irregularmente serrilhadas próximo ao ápice. Flores ca. $7 \mathrm{~cm}$ compr., sésseis; sépalas lineares, agudas e mucronadas, ca. 2,5 cm compr., concrescidas por ca. $7 \mathrm{~mm}$, carenadas, vinosas com borda alva; pétalas cuculadas, obtusas, eretas, alvas com ápice azul, com calosidades basais pouco evidentes; estames inclusos.

Distribuição geográfica e habitat: Bahia, Espírito Santo, Rio de Janeiro, São Paulo, Paraná, Santa Catarina e Rio Grande do Sul (Leme 2000). Floresta Pluvial Atlântica montana e baixo-montana, e nas restingas.

Material examinado: 3.XII.1991, fl., A. Costa et al. 408 (RB).

48. Nidularium scheremetiewii Regel, Ind. Sem. Hort. Petrop. 1857: 28. 1858; Smith \& Downs, Fl. Neotrop. Monogr. 14(3): 1627, fig. 531 A-C. 1979; Leme, Nidularium, Bromélias da Mata Atlântica, 67. 2000. Fig. 3 g

Planta florida 16-22 cm alt., epífita, rupícola, saxícola ou terrestre. Folhas suberetas, 16-64 cm compr., formando roseta infundibuliforme; bainha elíptica, 7-9 ×4,5 cm, verde a alvacenta, indumento castanho; lâmina linear, acuminada, serrilhada, 1-2 cm larg., verde com faixa longitudinal central mais clara. Escapo ereto, 7-10 cm compr., alvo; brácteas do escapo foliáceas, 9-22 cm compr., maiores que os entrenós, verdes. Inflorescência em espiga dupla, capituliforme, embutida até sobressaindo um pouco da roseta, ca. $7 \times 7$ cm; brácteas primárias com bainha ovada e lâmina triangular, acuminadas, serrilhadas, 4,5$11 \mathrm{~cm}$ compr., vermelhas; brácteas florais ovadas, agudas e minutamente apiculadas, irregularmente serrilhadas, $2-2,5 \times 0,7-0,9 \mathrm{~cm}$, carenadas. Flores sésseis, ca. 5,5 cm compr.; sépalas elípticas, ligeiramente assimétricas, agudas e minutamente apiculadas, 1,3-1,9 cm compr., concrescidas por 3-4 mm, carenadas, verde-claras a alvas; pétalas lineares, obtusas e cuculadas, eretas, 3,2-4 cm compr., alvas com ápice azul e margem alva na antese, 
passando a róseas na pós-antese, calosidades basais pouco evidentes; estames inclusos.

Distribuição geográfica e habitat: Smith \& Downs (1979) indicam sua ocorrência para o Espírito Santo, Rio de Janeiro, São Paulo e Santa Catarina. No entanto, Leme (2000) restringe sua distribuição ao Rio de Janeiro. Floresta Pluvial Atlântica montana.

Material examinado: 16.IV.1991, fl., A. Costa et al. 363 (RB); 3.XII.1991, fr., A. Costa et al. 401 (RB); 5.XII.1991, fl., A. Costa et al. 411 (RB); 25.X.1986, fl., G. Martinelli et al. 11831 (RB); 20.V.1987, fr., G. Martinelli et al. 12057(RB); 20.V.1987, fl., G. Martinelli et al. 12059 (RB); 20.V.1987, fl., G. Martinelli et al. 12059-A (RB); 2.II.1990, bot., H.C. Lima et al. 3792 (RB); 2.XII.1991, fr., T. Wendt \& A. Costa 208 (RB).

49. Quesnelia lateralis Wawra, Österr. Bot. Z. 30: 149. 1880; Smith \& Downs, Fl. Neotrop. Monogr. 14(3): 1963-6, fig. 680 A-C. 1979.

Fig. 2 e-f

Planta florida 30-65 cm alt., epífita, rupícola, saxícola ou terrestre. Folhas 35-140 cm compr., formando roseta infundibuliforme; bainha ovada 16-22 ×5-10 cm; lâmina linear, geralmente obtusa a aguda, cuspidadas, serreadas a serrilhadas, 3,5-6 cm larg., verdes. Escapo 33-65 cm compr., ereto, terminal ou axilar, vermelho; brácteas do escapo lineares, agudas e cuspidadas, inteiras, 3-11 cm compr., vermelhas, papiráceas, mais longas que os entrenós. Inflorescência em espiga, cilíndrica, 4-10 × 1,5-2 cm, densa, raque não visível; brácteas florais ovadas, agudas, inteiras, ca. 3 $\times 1,8 \mathrm{~cm}$, não carenadas, recobrindo as flores, vermelhas, papiráceas. Flores sésseis, ca. 4 cm compr., inteira ou parcialmente recobertas pelas brácteas florais; sépalas ovadas, simétricas, obtusas, concrescidas por ca. 3 mm, não carenadas, vermelhas; pétalas espatuladas, eretas, obtusas, ca. $3 \mathrm{~cm}$ compr., azuis, apêndices fimbriados; estames inclusos; ovário não sulcado.

Distribuição geográfica e habitat: Rio de Janeiro (Vieira 2006). Floresta Pluvial Atlântica montana. Material examinado: 16.IV.1991, fl., A. Costa et al. 365 (RB); 2.XII.1991, fl., A. Costa et al. 389 (RB); 4.XII.1991, fl., A. Costa et al. 406 (RB); 9-12.V.1988, fl., G. Martinelli et al. 12967 (RB); 18.IX.1986, fl.,
G. Martinelli \& T. Wendt 11755 (RB); 18.X.1977, J. P. P. Carauta et al. 2714 (GUA); 24.VIII.1986, fl., M. Leitman 138 (RB); 18.X.1977, fl., P. J. M. Maas \& G. Martinelli 3310 (RB); 17.VII.1987, fl., S. V.A. Pessoa et al. 225 (RB).

50. Quesnelia liboniana (De Jonghe) Mez, Bot. Archiv. 1: 66. 1922; Smith \& Downs, Fl. Neotrop. Monogr. 14(3): 1970-1, fig. 683 AE.1979.

Fig. 2 i-j

Planta florida $35-55 \mathrm{~cm}$ alt., estolonífera, epífita, rupícola, saxícola ou terrestre. Folhas eretas, 15-65 cm compr., formando roseta estreito-infundubuliforme; bainha ovada, 10$13 \times 5 \mathrm{~cm}$; lâmina linear, acuminada, serrilhada, 2-4 cm larg., verde. Escapo ereto a curvo, 28-40 cm compr., verde a vinoso; brácteas do escapo estreito-triangulares, acuminadas, inteiras, 1,5-4,5 cm compr., as inferiores mais longas que os entrenós e as superiores mais curtas, verdes. Inflorescência em espiga, 7$10 \times 4-5 \mathrm{~cm}$, laxa, raque visível; brácteas florais ovadas, longo-atenuadas, inteiras, 0,8-1,8 × 0,4$0,5 \mathrm{~cm}$, não recobrindo as flores, não carenadas, róseas a vermelhas. Flores sésseis, 4,5-5,5 cm compr.; sépalas oblongas, assimétricas, retusas, ca. 2 cm compr., não carenadas, vermelhas; pétalas espatuladas, eretas, obtusas, ca. $3,5 \mathrm{~cm}$ compr., azuis, apêndices fimbriados; estames inclusos; ovário não sulcado.

Distribuição geográfica e habitat: Rio de Janeiro, São Paulo e Minas Gerais (Vieira 2006). FlorestaPluvial Atlântica montana e baixo-montana. Material examinado: 12.IX.1990, fl., C. M. Vieira et al.106 (RB); 18.IX.1986, fl., G. Martinelli et al. 11719 (RB); 18.VI.1986, fl., G. Martinelli \& T. Wendt 11757 (RB); 26.VIII.1987, fl., M. Leitman 288(RB); 13.VII.1992, fl., M. Nadruz et al. 743 (RB); 2.XII.1991, fl., T. Wendt \& A. Costa 211 (RB).

51. Quesnelia strobilispica Wawra, Österr. Bot. Z. 30: 149. $1880 . \quad$ Fig. 2 g-h

Planta florida 44-60 cm alt., epífita. Folhas eretas, 25-43 cm compr., formando roseta infundibuliforme; bainha ovada, $15-20 \times 8-10 \mathrm{~cm}$, vinosa na face ventral; lâmina linear, pungente, serreada com acúleos de até $0,2 \times 4-6 \mathrm{~mm}$, verde. Escapo ereto, 35-45 cm compr., vermelho; brácteas 
do escapo elípticas, longo-atenuadas, inteiras, 4,5$5,5 \mathrm{~cm}$ compr., vermelhas, papiráceas, as inferiores mais curtas que os entrenós e as superiores mais longas tornando-se congestas abaixo da inflorescência e então semelhantes às brácteas florais. Inflorescência em espiga, rômbica, ca. $7 \times 4-4,5 \mathrm{~cm}$, densa, raque não visível; brácteas florais ovadas, agudo-apiculadas, inteiras, ca. $4 \times 1,3 \mathrm{~cm}$, recobrindo total ou parcialmente as flores, não carenadas, vermelhas, papiráceas. Flores sésseis; sépalas ovadas, ligeiramente assimétricas, agudas, ca. 1,5 cm compr., concrescidas por ca. $1 \mathrm{~mm}$, levemente carenadas, alvas na metade inferior e avermelhadas na superior; pétalas oblongas, eretas, obtusas, ca. $3 \mathrm{~cm}$ compr., azuis, apêndices fimbriados; estames inclusos; ovário não sulcado.

Distribuição geográfica e habitat: Espírito Santo, Minas Gerais e Rio de Janeiro (Vieira 2006). Floresta Pluvial Atlântica montana.

Material examinado: 5.XII.1991, fl., A. Costa et al. 409 (RB); 23.IX.1993, fl., C. M. Vieira \& L. C. Gurken 419 (RB).

\section{Distribuição Geográfica e Conservação}

Dentre as 51 espécies de Bromeliaceae registradas para a região de Macaé de Cima, 37 (ca. 72,5\%) ocorrem exclusivamente no domínio atlântico, com sete padrões de distribuição geográfica. O primeiro reúne duas espécies de ocorrência ao longo de toda a costa atlântica, nas florestas de encosta do Nordeste ao Sul ( $V$. heterostachys e $V$. flammea). O segundo grupo é formado por 12 espécies que ocorrem com predominância nas Regiões Sudeste e Sul, algumas podendo alcançar o sul da Bahia (e.g. B. pyramidalis, N. innocentii e $Q$. liboniana). O terceiro padrão inclui 12 espécies de ocorrência exclusiva nas formações florestais da Região Sudeste, das quais apenas $A$. pineliana atinge as restingas. No trecho fluminense da Serra do Mar, é observado o quarto e importante grupo de espécies de ocorrência entre Parati e Nova Friburgo (N. leucophoea), Petrópolis/ Teresópolis a Santa Maria Magdalena ( $A$. caesia, V. atra, V. triligulata, T. roseiflora especialmente acima de 1.000 m.s.m.), Teresópolis e Nova Friburgo ( $N$. fluminensis, $N$. lymaniana). O último grupo exclusivo do domínio atlântico é representado pelas espécies de distribuição restrita à região de Macaé de Cima e montanhas próximas: $A$. nevaresii, $N$. tenebrosa, $V$. altomacaensis e V. garlippiana.

As espécies B. sanderiana, P. flammea, $V$. bituminosa e $V$. longicaulis estendem sua distribuição atlântica até o Brasil-Central, em áreas de campos rupestres de Minas Gerais. Billbergia amoena e V. vagans ocorrem também em restingas.

Três outros padrões de distribuição mais amplos foram observados. Ananas bracteatus e T. geminiflora, possuem ocorrência na região meridional do continente sul-americano (Paraguai, Uruguai e Argentina), além da costa atlântica. Tillandsia stricta e $V$. procera atingem a Venezuela e as Guianas, em diversas formações, em um padrão peri-amazônico. E por último, T. tenuifolia e $R$. spiculosa possuem ampla distribuição na América do Sul e Central.

Quanto à conservação, sete espécies foram incluídas na revisão da Lista Brasileira de Espécies Ameaçadas realizada pela Fundação Biodiversitas em 2005 nas categorias CRITICAMENTE EM PERIGO ( $V$. hieroglyphica), EM PERIGO (A. imperialis e V. sparsiflora), e VULNERÁVEL ( $V$. altomacaensis, V. arachnoidea, V. bituminosa e $V$. triligulata). Outras três espécies ( $Q$. strobilispica, T. roseiflora e $V$. atra) foram consideradas como possuindo DADOS DEFICIENTES, o que faz da região de Macaé de Cima um importante remanescente florestal a ser preservado no Rio de Janeiro.

\section{Agradecimentos}

A. F. Costa agradece ao Dr. Jorge Fontella Pereira pela orientação e ao CNPq pela bolsa de mestrado concedida; e T. Wendt agradece ao CNPq pela bolsa de produtividade em pesquisa. Ao Programa Mata Atlântica/ JBRJ pelo suporte para o desenvolvimento do trabalho de campo. Aos revisores e editores pelas sugestões ao manuscrito. 


\section{REFERÊNCIAS BIBLIOGRÁFICAS}

Barbará, T.; Martinelli, G.; Fay, M. F.; Mayo, S. J. \& Lexer, C. 2007. Population differentiation and species cohesion in two closely related plants adapted to neotropical high-altitude 'inselbergs', Alcantarea imperialis and Alcantarea geniculata (Bromeliaceae). Molecular Ecology 16(10): 1981-1992.

Barros, J. V. 2006. O gênero Billbergia Thunb. (Bromeliaceae, Bromelioideae) no estado do Rio de Janeiro. Dissertação de Mestrado. Universidade Federal do Rio de Janeiro, Rio de Janeiro, 132p.

Benzing, D. H. 2000. Bromeliaceae, Profile for an adaptative radiation. Cambridge University Press, Cambridge, 690p.

Cogliatti-Carvalho, L.; Freitas, A. F. N.; Rocha, C. F. D. \& Van Sluys, M. 2001. Variação na estrutura e na composição de Bromeliaceae em cinco zonas de restinga no Parque Nacional da Restinga de Jurubatiba, Macaé, RJ. Revista Brasileira de Botânica 24(1): 1-9.

Costa, A. 1993. Vriesea Lindley (Bromeliaceae) na Reserva Ecológica de Macaé de Cima, Nova Friburgo, RJ. Dissertação de Mestrado. Universidade Federal do Rio de Janeiro, Rio de Janeiro, 134p.

Costa, A. F. 1995. A verdadeira identidade de Vriesea triligulata Mez. Bromélia 2(4): 3-9.

Costa, A. F. 1997. Nota sobre o Herbário e o Jardim Botânico da Universidade de Liège, Bélgica: a importância das coleções e o exemplo de Vriesea morreniana. Bromélia 4(4): 9-13.

Costa, A. F. 2002. Revisão taxonômica do complexo Vriesea paraibica Wawra (Bromeliaceae). Tese de Doutorado. Universidade de São Paulo, São Paulo, 187p.

Costa, A. F.; Wendt, T. \& Fontoura, T. 1997 Bromeliaceae. In: Marques, M. C. M. (org.). Mapeamento da cobertura vegetal e listagem das espécies ocorrentes na área de Proteção Ambiental de Cairuçú,
Município de Parati, RJ. Jardim Botânico do Rio de Janeiro, Rio de Janeiro. Pág. 88.

Costa, A. F.; Gusmão, L. C. T. \& Moura, R. L. 2001. Bromeliaceae. In: Costa, A. F. \& Dias, I. C. A. (orgs.). Flora do Parque Nacional da restinga de Jurubatiba e arredores, RJ: listagem, florística e fitogeografia (Angiospermas, Pteridófitas e Algas continentais). Museu Nacional/UFRJ, Rio de Janeiro. Pp. 45-48.

Faria, A.P.G. 2006. Revisão taxonômica de filogenia de Aechmea Ruiz \& Pav. subg. Macrochordion (De Vriese) Baker, Bromelioideae-Bromeliaceae. Tese de Doutorado. Universidade Federal do Rio de Janeiro. Rio de Janeiro. 199p.

Fontoura, T.; Costa, A. \& Wendt, T. 1991. Preliminary checklist of the Bromeliaceae of Rio de Janeiro State, Brazil. Selbyana 12: 5-45.

Fontoura, T.; Sylvestre, L. S.; Vaz, A. M. S. F. \& Vieira, C. M. 1997. Epífitas vasculares, hemiepífitas e hemiparasitas da Reserva Ecológica de Macaé de Cima. In: Lima, H. C. \& Guedes-Bruni, R. R. (orgs.). Serra de Macaé de Cima: Diversidade Florística e Conservação em Mata Atlântica. Instituto de Pesquisas Jardim Botânico do Rio de Janeiro, Rio de Janeiro. Pp. 89-101.

Forzza, R.C. 2005. Revisão taxonômica de Encholirium Mart. ex Schult. \& Schult. f. (Pitcairnioideae-Bromeliaceae). Boletim de Botânica da Universidade de São Paulo 23(1): 1-49.

Grant, J. R. \& Zijlstra, G. 1998. Na Annotated Catalogue of the Generic Names of the Bromeliaceae. Selbyana 19(1):91-121.

Guedes-Bruni, R. R. \& Lima, M. P. M. 1994. Abordagem geográfica, fitofisionômica, florística e taxonômica da Reserva Ecológica de Macaé de Cima. In: Lima, M. P. M. \& Guedes-Bruni, R. R. (orgs.). Reserva Ecológica de Macaé de Cima, Nova Friburgo, RJ, Aspectos Florísticos das Espécies Vasculares. Jardim Botânico do Rio de Janeiro, Rio de Janeiro. Pp. 17-54.

Leme, E. M. C. 1997. Canistrum, Bromélias da Mata Atlântica. Ed. Salamandra, Rio de Janeiro, 107p. 
Leme, E. M. C. 1998. Canistropsis, Bromélias da Mata Atlântica. Ed. Salamandra, Rio de Janeiro, 143p.

Leme, E. M. C. 2000. Nidularium, Bromélias da Mata Atlântica. Sextante, Rio de Janeiro, 264p.

Lima, H. C. \& Guedes-Bruni, R. R. (orgs.). 1997a. Serra de Macaé de Cima: Diversidade Florística e Conservação em Mata Atlântica. Instituto de Pesquisas Jardim Botânico do Rio de Janeiro, Rio de Janeiro, 345p.

Lima, H. C. \& Guedes-Bruni, R. R. 1997b. Diversidade de plantas vasculares na Reserva Ecológica de Macaé de Cima. In: Lima, H. C. \& Guedes-Bruni, R. R. (orgs.). Serra de Macaé de Cima: Diversidade Florística e Conservação em Mata Atlântica. Instituto de Pesquisas Jardim Botânico do Rio de Janeiro, Rio de Janeiro. Pp. 29-39.

Lima, M. P. M. \& Guedes-Bruni, R. R. (orgs.). 1994. Reserva Ecológica de Macaé de Cima, Nova Friburgo, RJ, Aspectos Florísticos das Espécies Vasculares. Vol. 1. Jardim Botânico do Rio de Janeiro, Rio de Janeiro, 404p.

Lima, M. P. M. \& Guedes-Bruni, R. R. (orgs.). 1996. Reserva Ecológica de Macaé de Cima, Nova Friburgo, RJ. Aspectos Florísticos das Espécies Vasculares. Vol. 2. Jardim Botânico do Rio de Janeiro, Rio de Janeiro, 465p.

Lima, M. P. M.; Guedes-Bruni, R. R.; Sylvestre, L. S. Pessoa, S. V. A. \& Andreata, R. H. P. 1997. Padrões de distribuição geográfica das espécies vasculares da Reserva Ecológica de Macaé de Cima. In: Lima, H. C. \& Guedes-Bruni, R. R. (orgs.). Serra de Macaé de Cima: Diversidade Florística e Conservação em Mata Atlântica. Instituto de Pesquisas Jardim Botânico do Rio de Janeiro, Rio de Janeiro. Pp. 103-123.

Luther, H.E. 2001. De Rebus Bromeliacearum III. Selbyana 22(1): 34-67. 2004. An alphabetic list of Bromeliad Binomials. The Marie Selby Botanical
Gardens. 9ed. Bromeliad Society International. Sarasota. \& Sieff, E. 1994. De Rebus Bromeliacearum I. Selbyana 15(1): 9-93. $\&$ 1997a. De Rebus

Bromeliacearum II. Selbyana 18(1): 103-140. \& 1997b. De Rebus

Bromeliacearum: Addenda et corrigenda. Selbyana 18(2): 215.

Martinelli, G. 1997. Biologia reprodutiva de Bromeliaceae na Reserva Ecológica de Macaé de Cima. In: Lima, H. C. de \& Guedes-Bruni, R. R. (orgs.). Serra de Macaé de Cima: Diversidade Florística e Conservação em Mata Atlântica. Instituto de Pesquisas Jardim Botânico do Rio de Janeiro, Rio de Janeiro. Pp. 213-250.

Mez, C. 1894. Bromeliaceae. In: Martius, C. F. P. von; Eichler, A. W. \& Urban, I. Flora brasiliensis. München, Wien, Leipzig, 3(3): 173-674.

Mez, C. 1896. Bromeliaceae. In: Candolle, A. L. P. P. \& Candolle, A. C. P. Monographiae Phanerogamarum. Paris, 9: 1-990.

1934-5. Bromeliaceae. In: Engler, H. G. A. Das Pflanzenreich. Berlin (Wilhem Engelmen), 4(32): 1-667 (Heft 100, 1-4).

Morren, E. 1882. Note sur le Vriesea psittacina Lindl. var. morreniana. Belgique Horticole 32: 289.

Moura, R. L.; Costa, A. F. \& Araujo, D. S. D. 2007. A família Bromeliaceae nas restingas fluminenses: florística e fitogeografia. Arquivos do Museu Nacional 65(2): 139-168.

Nunes-Freitas, A. F. 2005. Bromeliáceas da Ilha Grande: variação inter-habitats na composição, riqueza e diversidade da comunidade. Tese de Doutorado. Universidade do Estado do Rio de Janeiro. Rio de Janeiro, 195p.

Porembski, S. \& Barthlott, W. 1999. Pitcairnia feliciana: the only indigenous african bromeliad. Harvard Papers in Botany 4(1): 175-184.

Radford, A. E. 1986. Fundamentals of Plant Systematics. Harper \& Row, Publ. Inc., New York, 498p. 
Reitz, R. 1983. Bromeliáceas e a MaláriaBromélia Endêmica. In: Reitz, R. Flora Ilustrada Catarinense. Herbário Barbosa Rodrigues, Itajaí, Fasc. BROM, 559p.

Scarano, F. R.; Ribeiro, K. T.; Moraes, L. F. D. \& Lima, H. C. 1997. Plant establishment on flooded and unflooded patches in a swamp forest in southeastern Brazil. Journal of Tropical Ecology 14: 793-803.

Siqueira-Filho, J. A. \& Leme, E. M. C. 2006. Fragmentos de Mata Atlântica do Nordeste. Biodiversidade, conservação e suas bromélias. Andréa Jakobson Estúdio, Rio de Janeiro, 360p.

Smith, L. B. 1955. The Bromeliaceae of Brazil. Smithsonian Miscellaneous Collections 126(1): 1-290.

\& Downs, R. J. 1974. Bromeliaceae, subfamily Pitcairnioideae. Flora Neotropica Monograph 14(1): 1-658. \& 1977. Bromeliaceae, subfamily

Tillandsioideae. Flora Neotropica Monograph 14 (2): 663-1492.

$\&$ 1979. Bromeliaceae, subfamily

Bromelioideae. Flora Neotropica Monograph 14 (3): 1493-2142.

Sousa, G. M. 2004a. Revisão taxonômica de Aechmea Ruiz \& Pavon subg. Chevaliera (Gaudich. ex Beer) Baker Bromelioideae - Bromeliaceae. Tese de Doutorado. Universidade de São Paulo. São Paulo, 185p.

Sousa, G.M. \& Wanderley, M.G.L. 2000. Aechmea Ruiz \& Pav. (Bromeliaceae) do estado de Pernambuco, Brasil. Acta Botânica Brasílica 14(1): 77-97.

Sousa, L.O. 2004b. Revisão taxonômica e filogenia do gênero Lymania Read. (Bromelioideae-Bromeliaceae). Dissertação de Mestrado. Universidade Federal do Rio de Janeiro, Rio de Janeiro, 102p.

Ule, E. 1899. Utricularias epífitas. Arquivos do Museu Nacional do Rio de Janeiro 10: 185-189.

1900. Ueber weitere neue und interessante Bromeliaceen. Berichten der Deutschen Botanischen Gessellschaft 18: 312-327.

Vidal, U. A. 1995. A família Bromeliaceae na Reserva Ecológica Rio das Pedras, Mangaratiba, Rio de Janeiro. Dissertação de Mestrado. Universidade Federal do Rio de Janeiro, Rio de Janeiro, 156p.

Vieira, C. M. 2006. Quesnelia Gaudich. (Bromelioideae: Bromeliaceae) do Estado do Rio de Janeiro, Brasil. Pesquisas, Botânica 57: 7-102.

Wanderley , M. G. L. \& Mollo, L. 1992. Bromeliaceae. In: Melo, M. M. R. F.; Barros, F.; Chiea, S. A. C.; Wanderley, M. G. L.; Jung-Mendaçolli, S. L. \& Kirizawa, M. (eds.). Flora Fanerogâmica da Ilha do Cardoso. V.3. Instituto de Botânica, São Paulo. Pp: 89-140.

Wanderley, M.G. L. \& Forzza, R.C. 2003. Flora de Grão-Mogol, Minas Gerais: Bromeliaceae. Boletim de Botânica da Universidade de São Paulo 21(1): 131-139.

Weberling, F. 1989. Morphology of flowers and inflorescences. Cambridge University Press, Cambridge, 405p.

Wendt, T. 1994. Pitcairnia L'Héritier (Bromeliaceae) of Rio de Janeiro State, Brazil. Selbyana 15(2): 66-78.

1997. A review of the subgenus Pothuava (Baker) Baker of Aechmea Ruiz \& Pav. (Bromeliaceae) occuring in Brazil. Botanical Journal of the Linnean Society 125(3): 245-271. 